\title{
Calcium Signaling in Synapse-to-Nucleus Communication
}

\author{
Anna M. Hagenston and Hilmar Bading \\ CellNetworks-Cluster of Excellence, Department of Neurobiology, and the Interdisciplinary Center for \\ Neurosciences (IZN), University of Heidelberg, 69120 Heidelberg, Germany \\ Correspondence: Hilmar.Bading@uni-hd.de
}

\begin{abstract}
Changes in the intracellular concentration of calcium ions in neurons are involved in neurite growth, development, and remodeling, regulation of neuronal excitability, increases and decreases in the strength of synaptic connections, and the activation of survival and programmed cell death pathways. An important aspect of the signals that trigger these processes is that they are frequently initiated in the form of glutamatergic neurotransmission within dendritic trees, while their completion involves specific changes in the patterns of genes expressed within neuronal nuclei. Accordingly, two prominent aims of research concerned with calcium signaling in neurons are determination of the mechanisms governing information conveyance between synapse and nucleus, and discovery of the rules dictating translation of specific patterns of inputs into appropriate and specific transcriptional responses. In this article, we present an overview of the avenues by which glutamatergic excitation of dendrites may be communicated to the neuronal nucleus and the primary calcium-dependent signaling pathways by which synaptic activity can invoke changes in neuronal gene expression programs.
\end{abstract}

$T^{\text {he }}$ he significance of intracellular calcium $\left(\mathrm{Ca}^{2+}\right)$ increases for the regulation of gene expression in neurons is well established (Bading et al. 1997; Chawla 2002; Greer and Greenberg 2008; Redmond 2008; Hardingham and Bading 2010). Activity-dependent changes in gene expression in neurons participate in a broad range of processes and behaviors, including synaptic activity-induced acquired neuroprotection (Hardingham et al. 2002; Papadia et al. 2005; Zhang et al. 2007b, 2009; Lau and Bading 2009), activity-dependent regulation of synapse number, size, and function (Flavell et al. 2006; Shalizi et al. 2006; Saneyoshi et al. 2010;
Mauceri et al. 2011), modulation of dendritic complexity (Redmond et al. 2002; Mauceri et al. 2011), growth factor signaling (Gall and Lauterborn 1992; Castren et al. 1998; Greenberg et al. 2009), regulation of long-term changes in synaptic strength (Korzus et al. 2004; Limback-Stokin et al. 2004; Raymond and Redman 2006), and memory consolidation (Bailey et al. 1996; Pittenger et al. 2002; Limback-Stokin et al. 2004; Wood et al. 2005; Etkin et al. 2006; Mauceri et al. 2011). Increases in the intracellular concentration of $\mathrm{Ca}^{2+}\left(\left[\mathrm{Ca}^{2+}\right]_{\mathrm{i}}\right)$ that might trigger gene transcription as a consequence of neuronal activity are mediated by

Editors: Martin Bootman, Michael J. Berridge, James W. Putney, and H. Llewelyn Roderick

Additional Perspectives on Calcium Signaling available at www.cshperspectives.org

Copyright (C) 2011 Cold Spring Harbor Laboratory Press; all rights reserved; doi: 10.1101/cshperspect.a004564

Cite this article as Cold Spring Harb Perspect Biol 2011;3:a004564 
A.M. Hagenston and $\mathrm{H}$. Bading

$\mathrm{Ca}^{2+}$ entry through L-type voltage-dependent $\mathrm{Ca}^{2+}$ channels (VDCCs) and ligand-gated channels such as $\mathrm{N}$-methyl-D-aspartate receptors (NMDARs) (Bading et al. 1993, 1995) and $\alpha$-amino-3-hydroxyl-5-methyl-4-isoxazolepropionate receptors (AMPARs) (Jonas and Burnashev 1995; Cohen and Greenberg 2008), and by release of $\mathrm{Ca}^{2+}$ from the endoplasmic reticulum (ER) (Fig. 1) (Hardingham and Bading 1998; Power and Sah 2002, 2007; Stutzmann et al. 2003; Watanabe et al. 2006; Hagenston et al. 2008). $\mathrm{Ca}^{2+}$ transients that invade the cell nucleus appear to play a particularly important role in activity-dependent transcription (Hardingham et al. 1997, 2001b; Zhang et al. 2007b, 2009) and are critical for several longlasting adaptive responses, including acquired neuroprotection and memory formation (Bading 2000; Limback-Stokin et al. 2004; Papadia et al. 2005; Zhang et al. 2009, 2011; Mauceri et al. 2011).

Molecular studies of $\mathrm{Ca}^{2+}$-regulated genomic responses have largely focused on the interactions between synaptic excitation, the particular sources of cytoplasmic $\left[\mathrm{Ca}^{2+}\right]_{\mathrm{i}}$ increases, the stimulation of downstream identified signaling cascades, and the activation or repression of specific transcription factor targets. Prominent among the $\mathrm{Ca}^{2+}$ sources, $\mathrm{Ca}^{2+}$ dependent second messenger cascades, and transcription factors are NMDARs and L-type VDCCs, $\mathrm{Ca}^{2+} /$ calmodulin-dependent protein kinase (CaMK) and Ras/mitogen activated protein kinase (Ras/MAPK) signaling cascades, and the transcription factor cyclic AMP response element binding protein (CREB) as well as the ternary complex factor (TCF)/serum response factor (SRF) transcription factor complex (Fig. 2) (Bading et al. 1993; Xia et al. 1996; Cruzalegui and Bading 2000; Greer and Greenberg 2008). Briefly summarized, synaptically released glutamate binds to and activates NMDARs and AMPARs, leading to a depolarization of the postsynaptic membrane and the activation of L-type VDCCs. $\mathrm{Ca}^{2+}$ influx through synapse-associated dendritic NMDARs and L-type VDCCs is sensed by calmodulin $(\mathrm{CaM})$, which initiates a chain of signaling events including stimulation of CaMK and
Ras/MAPK cascades. The culmination of these and other kinase cascades is the phosphorylation and activation of a variety of transcription factors, most notably CREB, but also TCF, nuclear factor $\kappa \mathrm{B}(\mathrm{NF}-\kappa \mathrm{B})$, myocyte enhancer factor 2 (MEF2), and others (Cruzalegui and Bading 2000; Greer and Greenberg 2008). Several important genomic responses following neuronal activity are controlled by $\mathrm{Ca}^{2+}$ signals in the nucleus (Bading 2000; Zhang et al. 2009). For example, increases in nuclear $\left[\mathrm{Ca}^{2+}\right]_{\mathrm{i}}$ stimulate gene transcription indirectly through the nuclear resident $\mathrm{Ca}^{2+} /$ calmodulin-dependent protein kinase IV (CaMKIV) (Hardingham et al. 2001b) or directly by interaction with regulators of gene transcription such as transcription factor downstream regulatory element antagonistic modulator (DREAM) (Carrion et al. 1999; Ledo et al. 2002).

Cumulating evidence suggests that, in addition to regulating transcription via its influence on specific transcription factors, $\mathrm{Ca}^{2+}$ dependent modulation of genomic responses also operates at a global level by influencing chromatin structure. Nuclear $\mathrm{Ca}^{2+}$ signals acting via CaMKIV, for instance, stimulate the histone acetyltransferase CREB binding protein (CBP). Activated CBP, which interacts physically with numerous transcription factors (e.g., CREB) to promote transcription, influences gene transcription by catalyzing histone acetylation and subsequent chromatin decondensation (Chawla et al. 1998; Cruzalegui and Bading 2000; Alarcon et al. 2004; Korzus et al. 2004; Bedford et al. 2010). In a similar vein, nuclear $\mathrm{Ca}^{2+}$ signals induce the subcellular redistribution of class II histone deacetylases (HDACs), enzymes whose activity leads to chromatin compression and diminished accessibility by several transcription factors to their target binding sequences (Chawla et al. 2003; Tian et al. 2009, 2010b). Recent results indicate that also de novo DNA methylation, a mechanism stimulating global chromatin remodeling and gene transcription, is controlled by a neuronal activity and $\mathrm{Ca}^{2+}$-dependent mechanism (Chen et al. 2003; Martinowich et al. 2003; Zhou et al. 2006; Skene et al. 2010). $\mathrm{Ca}^{2+}$ dependent synapse-to-nucleus communication 


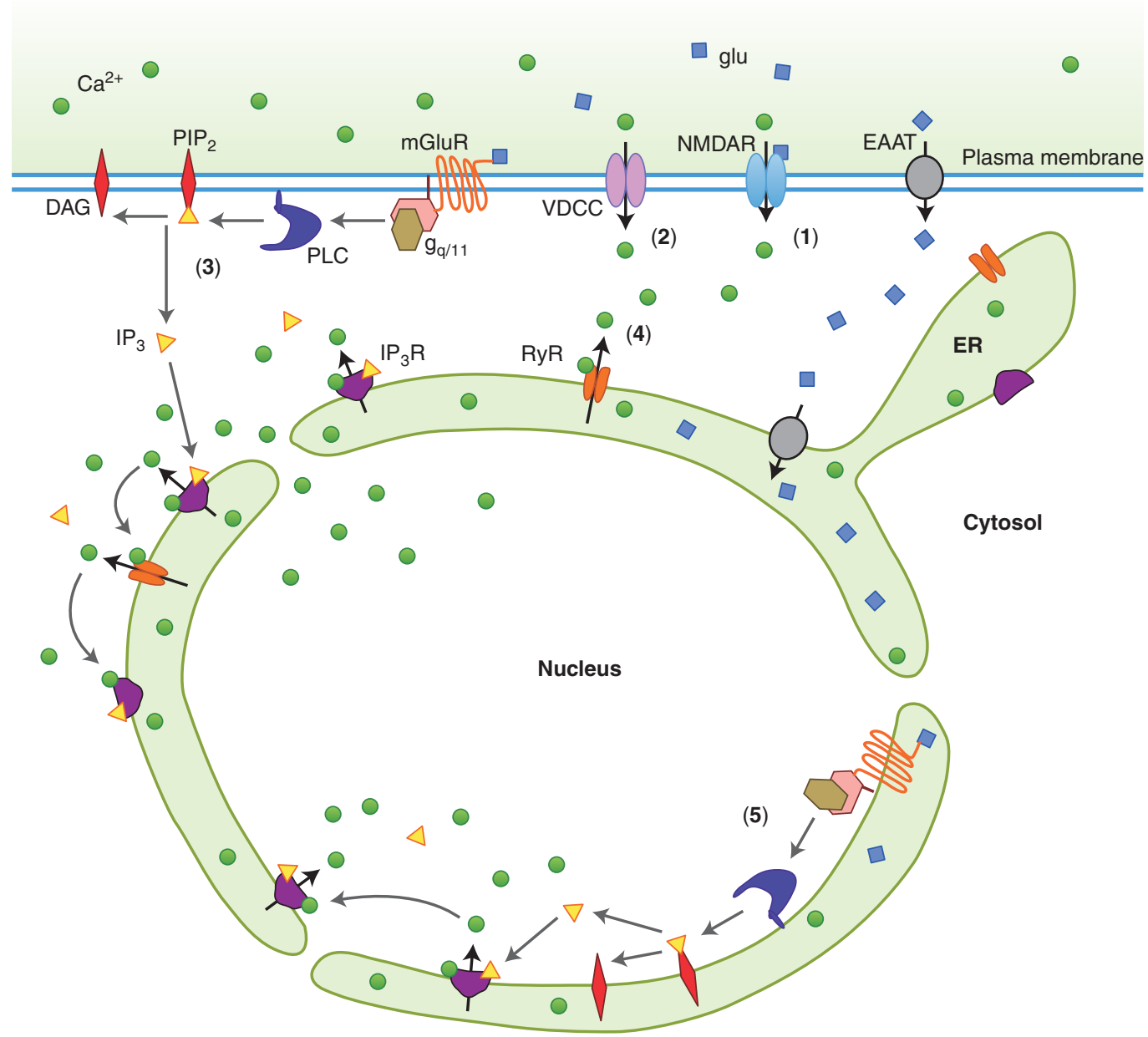

Figure 1. Sources of synaptic activity induced calcium signals. Here we consider five distinct routes by which $\mathrm{Ca}^{2+}$ may enter the neuronal cytoplasm. (1) $\mathrm{Ca}^{2+}$ may enter the cell from the extracellular space via ionotropic glutamate receptors, particularly NMDARs. (2) $\mathrm{Ca}^{2+}$ may also pass from the extracellular space into the cytoplasm by way of VDCCs, most notably the dihydropine-sensitive class of high voltage-activated, or L-type, VDCCs. (3) Stimulation of mGluRs can trigger release of $\mathrm{Ca}^{2+}$ into the cytoplasm from intracellular $\mathrm{Ca}^{2+}$ stores like ER: synaptically released glutamate activates mGluRs, which are coupled via $\mathrm{G}_{\mathrm{q} / 11}$ GTP-binding proteins to PLC. Activated PLC cleaves membrane-bound $\mathrm{PIP}_{2}$ to yield DAG and soluble $\mathrm{IP}_{3}$, which may then diffuse to and activate $\mathrm{IP}_{3} \mathrm{Rs}$ on the ER membrane. (4) Cytosolic $\mathrm{Ca}^{2+}$ signals originating from any of the ligand-gated glutamate receptors, VDCCs, or from $\mathrm{IP}_{3} \mathrm{Rs}$ can be amplified via the $\mathrm{Ca}^{2+}$-dependent activation of RyRs and subsequent internal release of $\mathrm{Ca}^{2+}$ from intracellular stores. (5) Synaptically released glutamate may activate mGluRs on the inner nuclear envelope subsequent to being taken up by EAATs on the plasma membrane first into the cytosol, and then by EAATs on the nuclear envelope into the nuclear lumen. Stimulation of intranuclear mGluRs may consequently lead to the release of $\mathrm{Ca}^{2+}$ directly into the nucleus from $\mathrm{IP}_{3} \mathrm{Rs}$ localized on the inner nuclear envelope.

therefore involves changes both in the activity of specific transcription factor targets as well as chromatin structure-dependent changes in the accessibility of transcription factors to their respective genomic binding sites.
One of the basic functions subserved by synaptic activity and $\mathrm{Ca}^{2+}$-dependent transcriptional regulation is the experience-dependent induction of persistent changes in synaptic efficacy. Long-term potentiation (LTP), an activity 
A.M. Hagenston and H. Bading

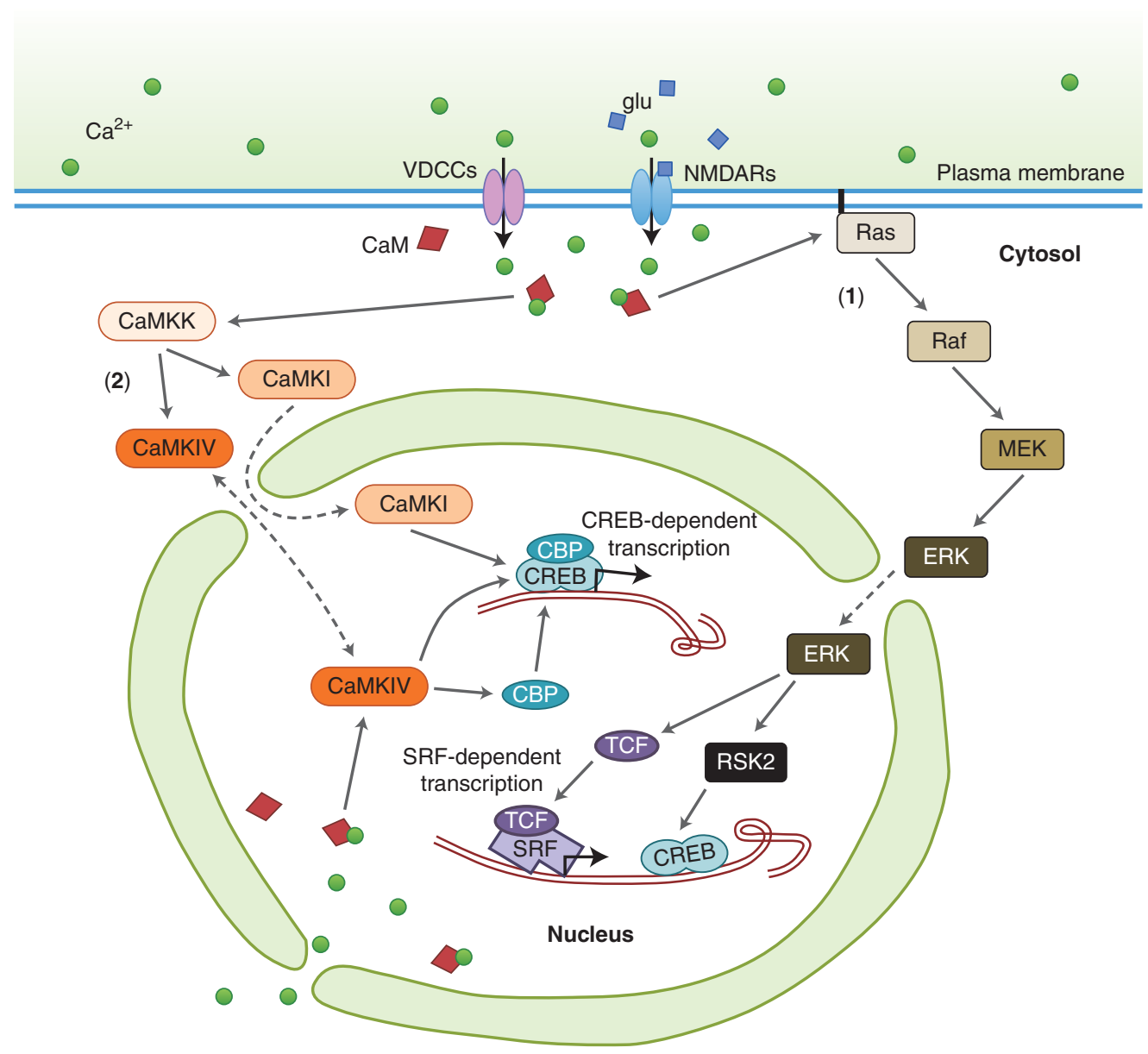

Figure 2. Activity-dependent gene expression in neurons is regulated by distinct calcium signaling pathways. Distinct activity-dependent genomic responses may be explained by the differential activation of regulatory signaling cascades and transcription factors. (1) $\mathrm{Ca}^{2+}$ influx through L-type VDCCs and synaptically activated NMDARs binds to and activates CaM, leading to activation of the GTP-binding protein Ras and subsequent induction of the Ras/MAPK signaling pathway. Ras binds and activates the mitogen activated protein kinase kinase kinase Raf. Raf in turn phosphoyrlates and activates MEK, which phosphoyrlates and activates ERK 1 and 2. Following its translocation into the nucleus, ERK can phosphorylate intermediate kinases like RSK2, which in turn phosphorylate CREB. ERK may also phosphorylate and activate the TCF-family transcription factors, which upon forming a complex with SRF may initiate gene transcription downstream from SRF binding sites. (2) CaM activation by $\mathrm{Ca}^{2+}$ entering through NMDARs and VDCCs, but especially through L-type VDCCs, also stimulates the CaMK signal transduction cascade. $\mathrm{Ca}^{2+} / \mathrm{CaM}$ binds to and activates CaMKK. Next, CaMKK phosphorylates and activates cytoplasmic CaMKI, which can in turn translocate into the nucleus (Sakagami et al. 2005; Wayman et al. 2008). CaMKK also phosphorylates $\mathrm{Ca}^{2+} / \mathrm{CaM-bound} \mathrm{CaMKIV}$. CaMKIV and perhaps also CaMKI can phosphorylate the transcription factor CREB (Wayman et al. 2008). Stimulation of CREB-mediated transcription, however, requires the additional activation by CaMKIV of the CREB coactivator CBP. It follows that VDCC and NMDAR-mediated $\left[\mathrm{Ca}^{2+}\right]_{\mathrm{i}}$ increases and subsequent activation of Ras/MAPK pathways are sufficient to induce TCF/SRF-dependent transcription. However, activation of CREB-dependent transcription necessitates the additional $\mathrm{Ca}^{2+}$-dependent stimulation of CaMKIV and CBP by nuclear $\mathrm{Ca}^{2+}$. 
induced persistent increase in synaptic efficacy, is thought to underlie certain forms of learning and memory in the mammalian brain. A critical event leading to the induction of LTP is the postsynaptic influx of $\mathrm{Ca}^{2+}$ (Raymond 2007). The persistence of LTP and that of other simple forms of synaptic plasticity is dependent on gene transcription taking place within approximately two hours of the instigating event (Nguyen et al. 1994; Arnold et al. 2005). Although it is unclear exactly which genes are critical for LTP, it is well established that genomic responses following synaptic activity and $\mathrm{Ca}^{2+}$ entry vary according to the selection of transcription factors these signals target (Greer and Greenberg 2008). Which transcription factors are activated depends, in turn, on the source and characteristics of stimulatory $\left[\mathrm{Ca}^{2+}\right]_{\mathrm{i}}$ increases and on the selection of intracellular signals they induce (Bading et al. 1993, 1997; Dudek and Fields 2001; Hardingham et al. 2002; Greer and Greenberg 2008). $\mathrm{Ca}^{2+}$ influx originating at L-type VDCCs and synaptic NMDARs, for example, couples to both CaMK and Ras/MAPK signaling pathways and can thus lead to the phosphorylation of both CREB and the SRF-associated factor, TCF (Cruzalegui and Bading 2000). However, while MAPK signaling is sufficient to stimulate TCF/SRF-dependent transcription, CREBdependent transcription requires the additional nuclear $\mathrm{Ca}^{2+}$-dependent activation of CaMKIV (Fig. 2) (Hardingham et al. 1997, 2001a,b; Chawla et al. 1998).

A second role for synaptic activity-dependent transcriptional regulation is in activating survival-promoting genes that enable neurons to build up a neuroprotective shield. Activitydependent neuronal survival is induced by $\mathrm{Ca}^{2+}$ entry through synaptic NMDARs and requires-for neuroprotection to be longlasting - that $\mathrm{Ca}^{2+}$ transients invade the cell nucleus, suggesting a mechanism involving CREB-mediated transcription (Wang et al. 1995; Hardingham et al. 2001b; Arnold et al. 2005; Zhang et al. 2007b; Hardingham 2009; Dick and Bading 2010). Procedures that interfere with electrical activity and compromise NMDAR function or nuclear $\mathrm{Ca}^{2+}$ signaling can have deleterious effects on neuron health. For example, the selective blockade of nuclear $\mathrm{Ca}^{2+}$ signaling prevents cultured hippocampal neurons from building up antiapoptotic activity upon synaptic NMDAR stimulation (Hardingham et al. 2002; Arnold et al. 2005; Papadia et al. 2005; Hardingham 2009; Lau and Bading 2009; Dick and Bading 2010). Conversely, enhancing neuronal firing and synaptic NMDAR activity is neuroprotective: networks of cultured hippocampal neurons that have experienced periods of action potential bursting causing $\mathrm{Ca}^{2+}$ entry through synaptic NMDARs show enhanced resistance to cell death-inducing stimuli (Hardingham et al. 2001b; Hardingham 2009; Lau and Bading 2009; Dick and Bading 2010). On the other hand, stimulation of extrasynaptic NMDARs (ES-NMDARs) counters these effects and activates proapoptotic signaling cascades (Hardingham et al. 2002, 2009; Vanhoutte and Bading 2003; Papadia et al. 2005; Zhang et al. 2007b, 2009, 2011; Leveille et al. 2008; Stanika et al. 2009; Wahl et al. 2009). In vitro studies using cultured neurons have revealed that two mechanistically distinct processes mediate the activity-dependent survival afforded by $\mathrm{Ca}^{2+}$ entry through synaptic NMDARs. One involves the PI3K-AKT pathway (reviewed in Hardingham 2009). The second requires $\mathrm{Ca}^{2+}$ signaling to the nucleus and the activation or inhibition of a variety of different target genes (Hardingham et al. 2001b, 2009; Francis et al. 2004; Lau and Bading 2009; Dick and Bading 2010). Within the pool of nuclear $\mathrm{Ca}^{2+}$-stimulated survival genes are a set of ten induced genes shown to provide neurons with a neuroprotective shield both in cell culture and in animal models of neurodegeneration (Zhang et al. 2009). Some of these genes, which were termed "Activity-Regulated Inhibitors of Death," or AID genes, may be induced by activation of the transcription factor CREB, and appear to protect neurons via a common process that yields mitochondria more resistant to cellular stressors and toxins (Zhang et al. 2007b, 2009, 2011; Lau and Bading 2009; Leveille et al. 2010). Another synaptic NMDAR-, nuclear $\mathrm{Ca}^{2+}$, , and CREB-dependent prosurvival gene is brain-derived neurotrophic factor 
A.M. Hagenston and $\mathrm{H}$. Bading

(BDNF), a synaptic plasticity associated neurotrophic factor whose expression can both protect neurons from future insult and rescue neurons from cell death induced by synaptic activity blockade (Favaron et al. 1993; Hardingham et al. 2002; Hansen et al. 2004; Jiang et al. 2005; Zhang et al. 2009).

\section{LOCAL $\mathrm{Ca}^{2+}$ SIGNALING HAS GLOBAL FUNCTIONAL CONSEQUENCES}

The predominance of excitatory synaptic transmission in the central nervous system occurs at dendritic protuberances called synaptic spines. These spines are distributed throughout the dendritic arbors of hippocampal and cortical pyramidal neurons. However, the soma, the first $\sim 100 \mu \mathrm{m}$ of the primary apical dendrite, and the first $30-50 \mu \mathrm{m}$ of the basal dendrites of these neurons are nearly devoid of spines (Spruston and Mcbain 2007). Indeed, the mean distance between the soma and the first synaptic spine is estimated to be $40 \mu \mathrm{m}$ (Bannister and Larkman 1995). Moreover, the most distal spines are situated on terminal branches many 100s of $\mu \mathrm{m}$ away from the soma (Spruston and Mcbain 2007). In view of the tight control placed on cytoplasmic $\mathrm{Ca}^{2+}$ transients by the numerous $\mathrm{Ca}^{2+}$ buffers, pumps, exchangers, and other $\mathrm{Ca}^{2+}$-binding proteins in neurons, these morphological features pose an interesting problem for $\mathrm{Ca}^{2+}$. dependent synapse-to-nucleus communication. At least three $\mathrm{Ca}^{2+}$-dependent routes have been proposed by which neurons may surmount this problem and successfully communicate synaptic excitation from spine to nucleus. Briefly, these are the diffusion and/or active transport and subsequent translocation of $\mathrm{Ca}^{2+}$-regulated proteins from their synaptic sites of activation into the nucleus (Fig. 3A) (Deisseroth et al. 1998; Mermelstein et al. 2001; Otis et al. 2006; Wiegert et al. 2007; Lai et al. 2008; Jordan and Kreutz 2009; Zehorai et al. 2010); the influx of $\mathrm{Ca}^{2+}$ through somatic and perisomatic VDCCs during excitatory postsynaptic potential (EPSP)- and action potential-associated depolarizations (Fig. 3B) (Westenbroek et al. 1990; Murphy et al. 1991;
Bading et al. 1993, 1995; Dudek and Fields 2002; Saha and Dudek 2008); and propagating inositol trisphosphate $\left(\mathrm{IP}_{3}\right)$ receptor $\left(\mathrm{IP}_{3} \mathrm{R}\right)$ dependent waves of internal $\mathrm{Ca}^{2+}$ release that invade the somatonuclear compartment (Fig. 3C) (Hardingham et al. 2001b; Power and Sah 2002, 2007; Watanabe et al. 2006; Hagenston et al. 2008). An additional means by which synaptic activity could be conveyed to the nucleus involves the passive propagation of electrical potentials along ER membranes to the nuclear envelope (Fig. 3D) (Shemer et al. 2008).

The first step in excitatory neurotransmission is the release of glutamate into the cleft between a presynaptic terminal and the electron-dense region of its apposing synaptic spine known as the postsynaptic density. This rich structure is composed of scaffolding molecules, cell adhesion proteins, glutamate receptors, VDCCs, and a wide array of signal transducers involved in the regulation of synaptic function, gene transcription, and memory (Okabe 2007). Therefore, in addition to generating EPSPs, the postsynaptic reception of glutamate by AMPARs and NMDARs may set into motion a wealth of intracellular signaling cascades through local interactions with second messengers. A central player in this relay is $\mathrm{Ca}^{2+}$, and its most prominent source in the postsynaptic density is the NMDAR (Cole et al. 1989; Xia et al. 1996; Pinato et al. 2009). NMDAR-mediated $\left[\mathrm{Ca}^{2+}\right]_{\mathrm{i}}$ increases in dendritic spines may be amplified by ryanodine receptor (RyR)-dependent $\mathrm{Ca}^{2+}$-induced $\mathrm{Ca}^{2+}$ release from spine ER (Emptage et al. 1999; Raymond and Redman 2006). Imaging studies suggest nonetheless that synaptic NMDAR-dependent $\mathrm{Ca}^{2+}$ transients are essentially confined within spine heads, with little to no invasion of dendritic shafts (Yuste et al. 2000; Nakamura et al. 2002; Sabatini et al. 2002; Noguchi et al. 2005). If not via the generation of global $\mathrm{Ca}^{2+}$ signals, synaptic NMDARs must communicate with the nucleus via locally activated $\mathrm{Ca}^{2+}$-regulated proteins and processes in the postsynaptic density. This idea is supported by studies employing exogenously applied EGTA. EGTA is a $\mathrm{Ca}^{2+}$ buffer that allows 
A

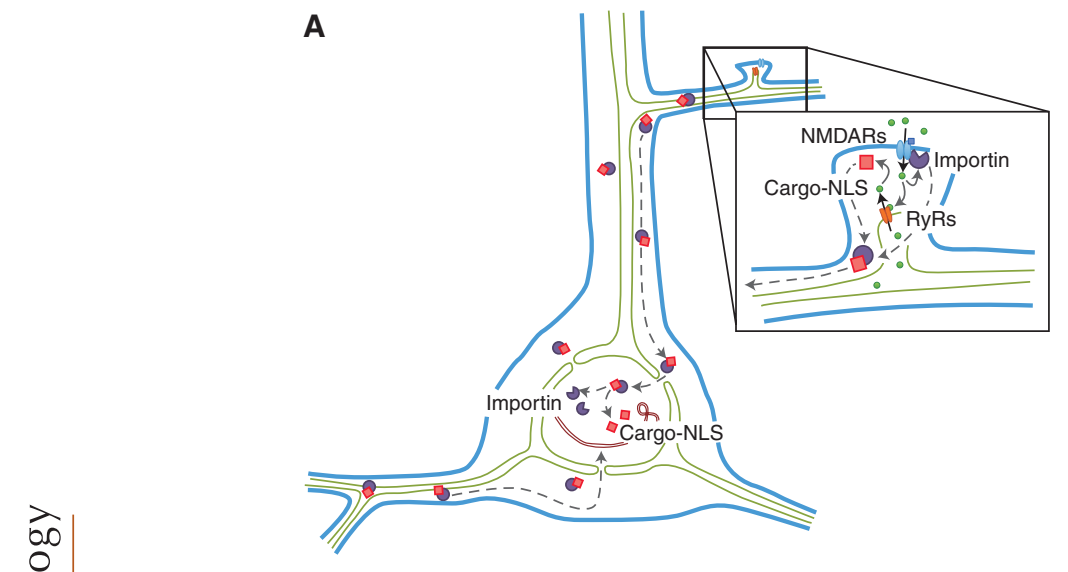

C

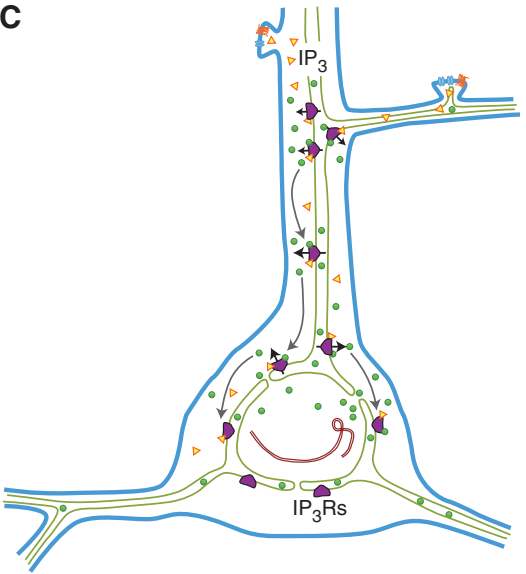

B

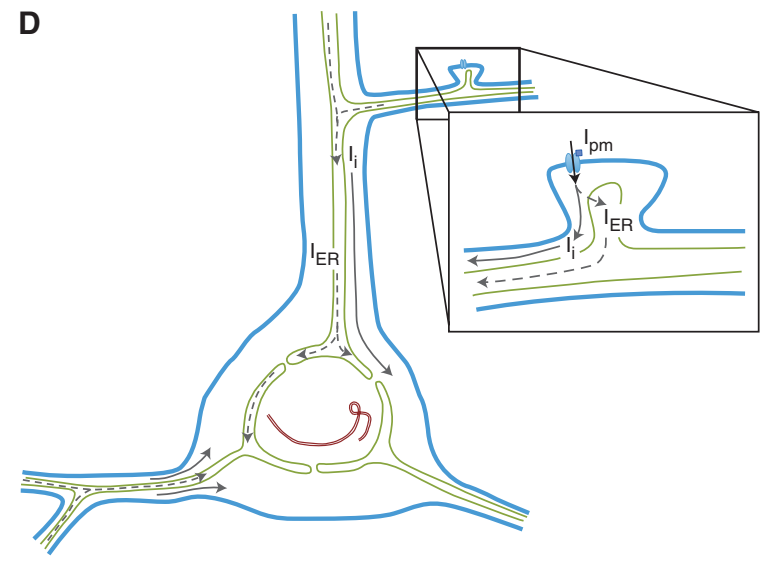

Figure 3. Possible routes of communication between synapse and nucleus. Schematic illustration of four pathways by which information impinging onto synapses may be conveyed to the nucleus. (A) Glutamatergic activation of synaptic AMPARs and NMDARs trigger increases in $\mathrm{Ca}^{2+}$ within synaptic spines. These $\mathrm{Ca}^{2+}$ increases may be amplified locally by $\mathrm{Ca}^{2+}$-induced $\mathrm{Ca}^{2+}$ release via RyRs on spinous ER. $\left[\mathrm{Ca}^{2+}\right]_{\mathrm{i}}$ increases within spines trigger the activation of numerous NLS-harboring second messengers (cargo-NLS) and the mobilization of importin. Importin/cargo complexes then diffuse or are actively transported through the dendritic cytosol to invade the soma and nucleus. (B) Synaptic activity evokes synaptic EPSPs, which travel along the plasma membrane to the soma. When the summation of inputs exceeds firing threshold, an action potential is triggered. Membrane depolarizations accompanying EPSPs and action potentials activate somatic and perisomatic L-type VDCCs, which allow $\mathrm{Ca}^{2+}$ to flow down its concentration gradient from the extracellular space into the soma, from where it crosses the nuclear envelope to invade the nucleus. $(C)$ Robust stimulation of glutamatergic afferents can result in the activation of perisynaptic $\mathrm{G}_{\mathrm{q} / 11}$-protein-coupled glutamate receptors, or mGluRs, which in turn trigger a signaling cascade that results in the production of the second messenger $\mathrm{IP}_{3}$. $\mathrm{IP}_{3}$ subsequently binds to and activates $\mathrm{IP}_{3} \mathrm{Rs}$ on the ER membrane, causing their $\mathrm{Ca}^{2+}$-permeable channels to open and allowing $\mathrm{Ca}^{2+}$ to flow down its concentration gradient from the ER lumen into the cytosol. $\mathrm{Ca}^{2+}$, an $\mathrm{IP}_{3} \mathrm{R}$ coagonist, may then stimulate neighboring $\mathrm{IP}_{3} \mathrm{Rs}$, thus triggering a propagating wave of regenerative internal $\mathrm{Ca}^{2+}$ release. Robust $\mathrm{Ca}^{2+}$ waves that invade the soma are able to freely cross the nuclear envelope and generate robust nuclear $\mathrm{Ca}^{2+}$ transients. $(D)$ Stimulation of ligand-operated and voltage-dependent ion channels in the plasma membrane of spines evokes local currents across the plasma membrane, $\mathrm{I}_{\mathrm{pm}}$. (Legend continued on next page.) 
A.M. Hagenston and $\mathrm{H}$. Bading

the generation of submembranous $\left[\mathrm{Ca}^{2+}\right]_{\mathrm{i}}$ increases near the mouth of $\mathrm{Ca}^{2+}$ influx channels, but prevents the spread of free $\mathrm{Ca}^{2+}$ from synaptic spines into the dendritic shaft and soma (Stern 1992; Deisseroth et al. 1996; Hardingham et al. 2001a). Introduction of EGTA into cultured hippocampal neurons thus effectively blocks global $\mathrm{Ca}^{2+}$ signaling, but permits the generation of cytoplasmic $\mathrm{Ca}^{2+}$ transients in the immediate vicinity of NMDARs. Under these conditions, synaptic activity has been observed to both induce Ras/MAPK signaling and trigger the phosphorylation of CREB (Deisseroth et al. 1996; Hardingham et al. 2001a).

\section{MOBILE SECOND MESSENGERS IN SYNAPSE-TO-NUCLEUS COMMUNICATION}

The diffusion and/or active transport of calcium-regulated proteins between synaptic NMDAR-associated $\mathrm{Ca}^{2+}$ signaling microdomains in the postsynaptic density and their targets in the nucleus represent attractive mechanisms for synapse-to-nucleus communication (Fig. 3A) (Deisseroth et al. 1998; Mermelstein et al. 2001; Thompson et al. 2004; Otis et al. 2006; Dieterich et al. 2008; Lai et al. 2008; Jordan and Kreutz 2009). The hypothesis that synaptic activity is relayed to the nucleus via mobile second messengers is supported by studies showing that NMDARs interact directly or indirectly with several different signaling molecules implicated in neuronal activity-dependent gene transcription, including $\mathrm{CaM}$, CaMKs, protein phosphatase 1 (PP1), calcineurin, and members of the Ras/MAPK signaling cascade (Seidenbecher et al. 1998; Graef et al. 1999; Westphal et al. 1999; Zuhlke et al.
1999; Husi et al. 2000; Dolmetsch et al. 2001; Tolias et al. 2005; Wheeler et al. 2008), as well as by studies showing that synaptic activation of NMDARs and VDCCs induces the active transport and nuclear import of a broad range of synaptically localized proteins involved in transcriptional regulation, including the transcription factors NF- $\mathrm{B}$, nuclear factor of activated T-cells (NFAT), and CREB2 (Graef et al. 1999; Wellmann et al. 2001; Meffert et al. 2003; Tomida et al. 2003; Fagerlund et al. 2008; Lai et al. 2008; Jordan and Kreutz 2009). In this regard, it is particularly interesting that NMDARs have been observed to interact also in an activity- dependent fashion with importin $\alpha$ (Thompson et al. 2004; Jeffrey et al. 2009), a soluble transport receptor that mediates the transport and/or nuclear import of a variety of nuclear localization signal (NLS)-containing cargoes from distal dendritic locations to the nucleus (Otis et al. 2006; Jordan et al. 2007; Dieterich et al. 2008; Lai et al. 2008). More specifically, the NR1-1a NMDAR subunit and importin $\alpha$ were recently reported to colocalize within synaptic spines and to coimmunoprecipitate in extracts derived from hippocampal neuronal cultures and acute slices (Jeffrey et al. 2009). These interactions were found to depend on the binding of importin $\alpha$ to an NLS sequence in the cytoplasmic tail of NR1-1a, and to be negatively regulated by phosphorylation of nearby residues via the $\mathrm{Ca}^{2+}$-dependent kinase protein kinase C. Accordingly, treatments that stimulate synaptic NMDARs and up-regulate protein kinase $\mathrm{C}$ activity-glutamate stimulation of neuronal cultures or high-frequency, LTP-inducing stimulation of presynaptic afferents in acute brain slices-were observed to disrupt the coimmunoprecipitation

Figure 3. (Continued) Either as a result of capacitative conduction of plasma membrane potential fluctuations combined with $\mathrm{Ca}^{2+}$ uptake into the ER via sarcoendoplasmic reticulum $\mathrm{Ca}^{2+}$ ATPases, or as a consequence of the release of $\mathrm{Ca}^{2+}$ via RyRs and $\mathrm{IP}_{3} \mathrm{Rs}$ localized to spines and dendrites, synaptic currents are predicted to evoke an electrotonic signal across and along the ER membrane, such that synaptic currents flow simultaneously through the cytosol $\left(\mathrm{I}_{\mathrm{i}}\right)$ and within the ER $\left(\mathrm{I}_{\mathrm{ER}}\right)$ toward the soma. Summation of many such excitatory electrotonic signals can give rise to an EPSP-like depolarization across the nuclear envelope. Importantly, action potentials initiating at the soma would also result in propagating electrotonic signals along the ER. In this case, however, the resultant changes in potential across the nuclear envelope would be hyperpolarizing, thereby distinguishing these signals from others that originate distally in synaptic spines. 
and colocalization of NR1-1a with importin $\alpha$ (Jeffrey et al. 2009). These findings suggest a mechanism by which importin $\alpha$ may be made available in a $\mathrm{Ca}^{2+}$ - and activity-dependent fashion to facilitate the transport and translocation of synaptically localized NLS-harboring proteins such as NFAT to the nucleus.

Might such a mechanism underlie synaptic activity regulated genomic responses through the Ras/MAPK signaling cascade? Until recently, there were no indications either that the MAPKs harbor an NLS enabling binding to importins or that they might interact with another NLS-containing protein (Lange et al. 2007; Zehorai et al. 2010). These findings made it difficult to clarify evidence suggesting that the nuclear translocation of extracellular signal-regulated kinase (ERK), a key player in Ras/MAPK signaling within the nucleus, was mediated by both facilitated diffusion and active transport mechanisms (Adachi et al. 1999; Xu and Massague 2004; Zehorai et al. 2010). A recent study introduced the possibility, however, that nuclear import of ERK may be controlled by its interaction with a member of the importin $\beta$ family of nuclear import proteins (Chuderland et al. 2008). In this study, the authors identified a novel nuclear transport sequence in ERK's kinase insert domain that enabled ERK to bind importin $\beta$ and diffuse across the nuclear envelope. ERK's interaction with importin $\beta$ necessitated its prior phosphorylation by MAPK/ERK kinase (MEK) and consequent release from anchoring proteins into the cytoplasm (Chuderland et al. 2008). These findings suggest that importindependent transport is likely to contribute to the somatonuclear translocation of active, diffusible ERK. They do not, however, resolve the question of whether ERK translocation from distal dendritic processes into the soma is likewise facilitated by an active transport mechanism involving importins (Thompson et al. 2004; Otis et al. 2006; Lai et al. 2008). We would suggest that this is an unlikely scenario. NMDAR-dependent $\left[\mathrm{Ca}^{2+}\right]_{\mathrm{i}}$ increases activate the Ras/MAPK pathway through a $\mathrm{Ca}^{2+}$ pool in their immediate vicinity (Hardingham et al. 2001a), and synaptically activated Ras spreads along dendrites by diffusion, reaching distances of only $\sim 10 \mu \mathrm{m}$ from its spine of origin before inactivating (Harvey et al. 2008). In an investigation employing exogenously expressed ERK fused to a photoactivable and photobleachable probe, it was found that synaptic activity similarly mobilizes the Ras effectors ERK 1 and 2, and that their trafficking in dendrites likewise proceeds by passive diffusion (Wiegert et al. 2007). Significantly, ERK was observed in this study to have a very limited reach within dendrites, and showed a length constant of only $\sim 30 \mu \mathrm{m}$ (Wiegert et al. 2007). These findings indicate that successful signal propagation to the nucleus by the Ras/MAPK pathway most probably depends on the distance between the nucleus and the site of activated synapses. Thus, while perisomatic synaptic NMDAR activation and subsequent ERK mobilization may suffice to trigger new ERK-dependent nuclear responses, distal synaptic NMDARs are unlikely to stimulate transcription through the Ras/ MAPK signaling cascade (Wiegert et al. 2007).

Phosphorylation and activation of CREB following synaptic NMDAR activity is achieved by the convergence of at least two $\mathrm{Ca}^{2+}$. dependent kinase pathways: CaMKIV in the nucleus mediates rapid CREB phosphorylation whereas the Ras/MAPK pathway acting through ERK promotes CREB phosphorylation in a slower, but more long-lasting manner (Hardingham et al. 2001a; Wu et al. 2001). For its part, CaMKIV activation requires that it bind $\mathrm{Ca}^{2+}$-activated calmodulin $\left(\mathrm{Ca}^{2+} / \mathrm{CaM}\right)$ and be phosphorylated by cytosolic $\mathrm{Ca}^{2+} /$ calmodulin-dependent protein kinase kinase (CaMKK) to achieve an enzymatically active state (Anderson et al. 1998; Means 2000; Sakagami et al. 2000). The reported constitutive localization of CaMKIV within the nucleus (Jensen et al. 1991; Nakamura et al. 1995; Bito et al. 1996) combined with its requisite involvement in the activation of CREB-mediated transcription (Chawla et al. 1998) raised the possibility that CREB induction via CaMKIV involves the translocation of a synaptically activated $\mathrm{Ca}^{2+}$ effector such as CaM or CaMKK. Stimulustriggered $\left[\mathrm{Ca}^{2+}\right]_{\mathrm{i}}$ increases have been reported to induce the rapid translocation of both 
A.M. Hagenston and $\mathrm{H}$. Bading

endogenous $\mathrm{Ca}^{2+} / \mathrm{CaM}$ and fluorescently labeled $\mathrm{Ca}^{2+} / \mathrm{CaM}$ from the cytoplasm to the nucleus of cultured hippocampal neurons, possibly in a complex with CaMKK (Deisseroth et al. 1998; Mermelstein et al. 2001). However, these findings are inconsistent both with the observed prominent nuclear localization of $\mathrm{CaM}$ in cortical and hippocampal neurons in vivo and in vitro (Caceres et al. 1983; Hoskins et al. 1986; Hardingham et al. 2001b), and with the lack of evidence supporting CaMKK nuclear localization or translocation (Deisseroth et al. 1998; Sakagami et al. 2000). Moreover, in a similar series of experiments, no evidence was found for signal-regulated translocation either of endogenous CaM or of microinjected fluorescently labeled CaM (Hardingham et al. 2001b). Instead, it was observed that rapid CaMK-dependent CREB phosphorylation can be evoked even when nuclear transport is blocked, and that an increase in nuclear $\left[\mathrm{Ca}^{2+}\right]_{\mathrm{i}}$ suffices to induce this response (Hardingham et al. 2001b).

Following these studies, a model has emerged for the activation of CaMKIV, which involves not the nuclear translocation of CaM, but rather the generation of nuclear calcium transients. Accordingly, the initial stimulation of CaMKIV begins with an increase in nuclear $\left[\mathrm{Ca}^{2+}\right]_{\mathrm{i}}$ and a physical association between CaMKIV and nuclearly localized $\mathrm{Ca}^{2+} / \mathrm{CaM}$ (Hardingham et al. 2001b; Anderson et al. 2004). Binding of $\mathrm{Ca}^{2+} / \mathrm{CaM}$ by CaMKIV is accompanied by its disengagement from the negative regulator protein phosphatase $2 \mathrm{a}$ (Park and Soderling 1995; Westphal et al. 1998; Kasahara et al. 1999; Anderson et al. 2004) and is followed by its phosphorylation and activation through CaMKK (Anderson et al. 1998, 2004; Chow et al. 2005). Interestingly, although CaMKK is triggered by $\left[\mathrm{Ca}^{2+}\right]_{\mathrm{i}}$ increases, it also shows a substantial level of activity at basal $\left[\mathrm{Ca}^{2+}\right]_{\mathrm{i}}$ (Anderson et al. 1998). It follows that synaptic activity-associated nuclear $\left[\mathrm{Ca}^{2+}\right]_{\mathrm{i}}$ increases may be sufficient for stimulating CaMKIV-dependent CREB phosphorylation (Chawla et al. 1998; Hardingham et al. 2001b). Yet where does the phosphorylation of CaMKIV occur? Although
CaMKIV is localized to the nucleus, it has been observed to dynamically redistribute between cytoplasmic and nuclear compartments (Matthews et al. 1994; Lalonde et al. 2004; Lemrow et al. 2004; Kotera et al. 2005). CaMKK, on the other hand, shows a strictly cytoplasmic distribution (Anderson et al. 1998; Sakagami et al. 2000). Thus, CaMKIV appears to be phosphorylated by CaMKK in the cytoplasm (Lemrow et al. 2004), after which it is transported into the nucleus, perhaps via a mechanism involving importin $\alpha$-mediated facilitated diffusion (Matthews et al. 1994; Lemrow et al. 2004; Kotera et al. 2005).

VDCCs are important for the neuronal activity-dependent regulation of gene expression. Neurons express a variety of VDCCs having varying pharmacological sensitivity, activation thresholds, conductances, and localizations (Catterall et al. 2005; Vacher et al. 2008). Of these, the L-type family of high voltage-activated VDCCs plays the most prominent role in postsynaptic signal transduction to the nucleus. These $\mathrm{Ca}^{2+}$ channels are expressed in the soma and proximal dendrites at both synaptic and extrasynaptic locations (Westenbroek et al. 1990; Hell et al. 1993; Obermair et al. 2004; Leitch et al. 2009), and are strongly implicated in the somatodendritic $\left[\mathrm{Ca}^{2+}\right]_{\mathrm{i}}$ increases that are generated in response to action potentials (Westenbroek et al. 1990; Liu et al. 2003; Vacher et al. 2008). In view of their somatodendritic localization, it may be tempting to conclude that the involvement of L-type channels in transcriptional regulation can be accounted for solely through the global $\mathrm{Ca}^{2+}$ transients associated with their activation. Numerous studies have shown, however, as is the case for NMDARs, that $\mathrm{Ca}^{2+}$ can act locally near the mouth of the channel to trigger transcriptionrelevant events (Deisseroth et al. 1996; Dolmetsch et al. 2001; Hardingham et al. 2001a; Weick et al. 2003; Wheeler et al. 2008). This reliance of VDCC-mediated genomic responses on local $\mathrm{Ca}^{2+}$ signaling suggests that L-type channels reside within $\mathrm{Ca}^{2+}$ signaling microdomains in close physical proximity to $\mathrm{Ca}^{2+}$-dependent molecular machinery. Indeed, not only are L-type VDCCs localized to postsynaptic 
densities in synaptic spines, where they interact with CaM, CaMKs, the $\mathrm{Ca}^{2+}$-dependent protein phosphatase calcineurin, and other $\mathrm{Ca}^{2+}$ dependent second messengers (Graef et al. 1999; Weick et al. 2003; Greer and Greenberg 2008; Vacher et al. 2008; Wheeler et al. 2008; Dai et al. 2009), the L-type channel also harbors a CaM-binding motif on its carboxy-terminus enabling the tethering of $\mathrm{CaM}$ within several nanometers of its $\mathrm{Ca}^{2+}$-conductive pore (Zuhlke and Reuter 1998; Dolmetsch et al. 2001). Consistent with these findings, L-type VDCC-dependent phosphorylation of transcriptional activators has been reported to depend-at least in part-on the activation of synaptically localized $\mathrm{Ca}^{2+} / \mathrm{CaM}$-dependent kinases (Deisseroth et al. 1998; Dolmetsch et al. 2001; Weick et al. 2003; Wheeler et al. 2008). An additional means by which synaptic L-type channels can control genomic responses is via local interactions with the protein kinase $\mathrm{A}$ anchoring protein (AKAP79/150) and the protein phosphatase calcineurin (Gray et al. 1998; Oliveria et al. 2007). In particular, anchoring of calcineurin to L-type VDCCs by AKAP79/ 150 is thought to facilitate its activation by L-type VDCC-mediated $\mathrm{Ca}^{2+}$ influx. $\mathrm{Ca}^{2+}$ activated calcineurin, in turn, can dephosphorylate the transcription factor NFAT, unmasking its NLS and leading to nuclear import (Beals et al. 1997; Graef et al. 1999; Greer and Greenberg 2008; Vashishta et al. 2009).

\section{EXTRASYNAPTIC NMDA RECEPTORS ANTAGONIZE SYNAPSE-TO-NUCLEUS COMMUNICATION}

Up to this point, we have concentrated on delineating the routes by which glutamatergic synaptic input may be conveyed to the nucleus. Just as significant, however, are the extrasynaptic routes by which glutamatergic excitationtranscription coupling is controlled. In the brain, signal reception by extrasynaptic glutamate receptors, particularly ES-NMDARs, has been suggested to play a pivotal role in the neurodegenerative processes associated with cerebral ischemia, seizure, and traumatic brain injury. ES-NMDARs are also implicated in the etiology of several neurodegenerative disorders, including Huntington's disease, Alzheimer's disease, and amyotrophic lateral sclerosis (Hardingham and Bading 2003, 2010; Vanhoutte and Bading 2003; Arundine and Tymianski 2004; Bossy-Wetzel et al. 2004; Bezprozvanny 2007; Kalia et al. 2008; Hardingham 2009; Milnerwood et al. 2010). The functional importance of ES-NMDARs in these disorders has been proposed to follow from their influence on cell survival and cell death pathways.

Although $\mathrm{Ca}^{2+}$ entry through synaptic NMDARs promotes neuronal survival via the activation of a neuroprotective gene program and suppression of apoptotic cascades, $\mathrm{Ca}^{2+}$ influx through ES-NMDARs both opposes cell survival pathways and triggers cell death signals leading to neuron loss (Hardingham et al. 2002, 2009; Vanhoutte and Bading 2003; Papadia et al. 2005; Zhang et al. 2007b, 2009; Leveille et al. 2008; Stanika et al. 2009; Wahl et al. 2009). For example, synaptic NMDAR activation both inhibits transcription of the proapoptotic gene Puma and triggers the nuclear $\mathrm{Ca}^{2+}$ - and CREB-dependent expression of AID genes and the prosurvival immediate early gene, $B D N F$ (Favaron et al. 1993; Hardingham et al. 2002; Hansen et al. 2004; Jiang et al. 2005; Zhang et al. 2007b, 2009; Lau and Bading 2009; Leveille et al. 2010). Conversely, stimulation of extrasynaptic receptors is linked to up-regulated expression of the proapoptotic putative $\mathrm{Ca}^{2+}$ activated chloride channel Clcal (Zhang et al. 2007b; Wahl et al. 2009). Moreover, ES-NMDARs activate a dephosphorylating CREB shut-off pathway and antagonize synaptic activity induced BDNF expression and cell survival (Hardingham and Bading 2002; Hardingham et al. 2002; Vanhoutte and Bading 2003; Papadia et al. 2005; Ivanov et al. 2006; Zhang et al. 2007b).

One important messenger in synaptic NMDAR- and $\mathrm{Ca}^{2+}$-dependent coupling to CREB is ERK. Although $\mathrm{Ca}^{2+}$ influx through synaptic NMDARs induces the phosphorylation and mobilization of ERK, $\mathrm{Ca}^{2+}$ entry via ES-NMDARs instead leads to ERK inactivation and retention at the plasma membrane, thus preventing its interaction with and activation of nuclear transcription factor targets (Cruzalegui and Bading 2000; Krapivinsky et al. 2003; 
A.M. Hagenston and $\mathrm{H}$. Bading

Ivanov et al. 2006; Leveille et al. 2008; Zehorai et al. 2010). Consequently, stimulation of the total (synaptic and extrasynaptic) NMDAR pool triggers a reduced level of ERK activity and associated transcription factor activation (Bading and Greenberg 1991; Chandler et al. 2001; Hardingham et al. 2001a, 2002; Krapivinsky et al. 2003; Ivanov et al. 2006; Leveille et al. 2008; Gao et al. 2010). Such antagonism by ES-NMDARs of synaptic NMDAR-dependent signaling to the nucleus extends to a number of additional signaling pathways. For example, ES-NMDAR signaling has been observed to disrupt the nucleocytoplasmic shuttling of class II HDACs, thereby preventing disinhibition of prosurvival transcription factors MEF2 and CREB in response to synaptic NMDAR stimulation (Chawla et al. 2003; Vanhoutte and Bading 2003; Bolger and Yao 2005). Furthermore, synaptic NMDARs signals promote the phosphorylation and subsequent nuclear export of the forkhead box O (FOXO) family of proapoptotic transcription factors, and also inhibit subsequent FOXO nuclear import. Stimulation of ES-NMDARs, on the other hand, induces rapid translocation of FOXO from the cytoplasm into the nucleus (Brunet et al. 1999; Gilley et al. 2003; Al-Mubarak et al. 2009; Hardingham 2009; Dick and Bading 2010). A picture is thus emerging in which neurons' genomic responses to $\mathrm{Ca}^{2+}$ entry through NMDARs depends on the subcellular localization of these receptors (Fig. 4). The particular means by which ES-NMDARs antagonize intracellular signals induced by synaptic NMDARs remains to be clearly delineated. One intriguing possibility is that the two receptor populations experience distinct biochemical environments harboring different sets of $\mathrm{Ca}^{2+}$-dependent effector molecules (Hardingham and Bading 2010).

\section{NUCLEAR $\mathrm{Ca}^{2+}$ SIGNALING IN SYNAPSE- TO-NUCLEUS COMMUNICATION}

An increasing number of studies suggest that $\left[\mathrm{Ca}^{2+}\right]_{\mathrm{i}}$ increases within the nucleus represent an essential component of synapse-to-nucleus communication: nuclear $\mathrm{Ca}^{2+}$ signals have been implicated in the regulation of neuronal gene expression programs (Chawla et al. 1998; Carrion et al. 1999; Ledo et al. 2000; Hardingham et al. 2001b; Ledo et al. 2002; Zhang et al. 2009) and are a critical component in the molecular machinery that translates different sets of stimuli into distinct transcriptional responses (Hardingham et al. 1997; Mellstrom et al. 2004). Nuclear $\mathrm{Ca}^{2+}$ signaling is linked also to a number of neuronal functions that have been shown to depend on regulated gene expression (Limback-Stokin et al. 2004; Papadia et al. 2005; Raymond and Redman 2006; Schneider et al. 2007; Alexander et al. 2009; Fontan-Lozano et al. 2009). For instance, $100 \mathrm{~Hz}$ and $\theta$-burst synaptic stimulation of afferent fibers-both of which are known to induce transcription-dependent LTP-evoke robust nuclear $\mathrm{Ca}^{2+}$ transients (Raymond and Redman 2002, 2006; Johenning and Holthoff 2007; Power and Sah 2007). Conversely, blockade of somatonuclear $\left[\mathrm{Ca}^{2+}\right]_{\mathrm{i}}$ increases during stimulation prevents the development of transcription-dependent, but not transcription-independent LTP (Raymond and Redman 2002, 2006), whereas antagonism of nuclear $\mathrm{Ca}^{2+} / \mathrm{CaM}$ signaling inhibits both neuronal activity-induced gene transcription and transcription-dependent LTP, and selectively prevents the formation of transcription-dependent longterm memory (Limback-Stokin et al. 2004). The means by which nuclear $\mathrm{Ca}^{2+}$ signaling controls memory processes include the transcriptional regulation of vascular endothelial growth factor D (VEGFD), a mitogen for endothelial cells whose expression modulates dendritic length and complexity (Mauceri et al. 2011). Nuclear $\mathrm{Ca}^{2+} / \mathrm{CaM}$ signaling is also critically important for the activation of a neuroprotective gene program, and its inhibition has been linked to an increased susceptibility to cellular stressors (Papadia et al. 2005; Zhang et al. 2007b, 2009; Lau and Bading 2009; Dick and Bading 2010).

The first indication that nuclear $\mathrm{Ca}^{2+}$ might play a part distinct from cytoplasmic $\mathrm{Ca}^{2+}$ in the neuronal activity-dependent regulation of gene expression was gained by an investigation employing a dextran-conjugated $\mathrm{Ca}^{2+}$ chelator (Hardingham et al. 1997). AtT20 cells, into whose nuclei this chelator had been injected, 


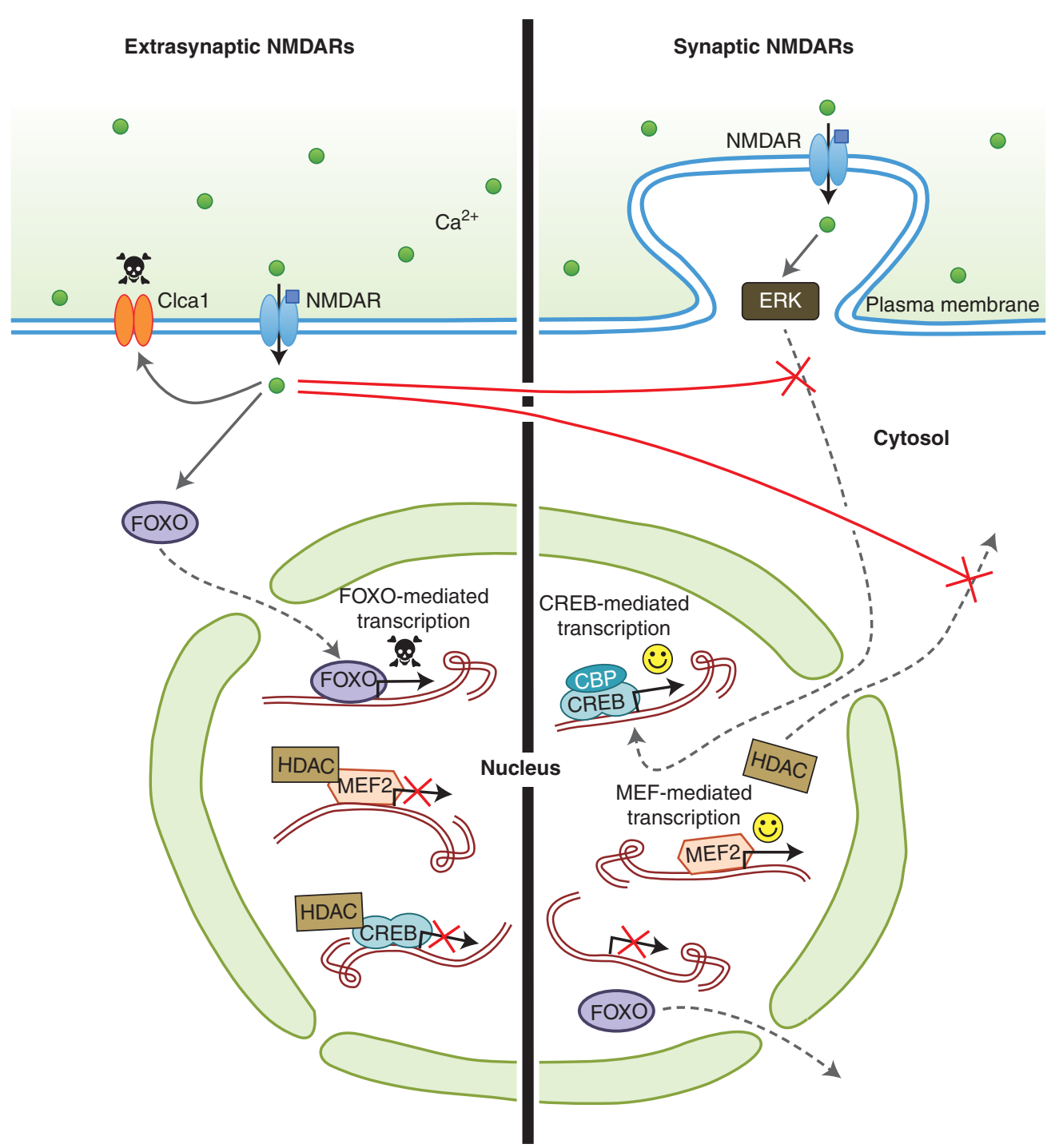

Figure 4. Extrasynaptic NMDARs antagonize synaptic NMDAR-dependent synapse-to-nucleus signaling. NMDAR-dependent $\mathrm{Ca}^{2+}$ signaling promotes neuronal survival, but can also cause cell degeneration and apoptotic death. The location of the activated NMDAR pool specifies the transcriptional response. In particular, $\mathrm{Ca}^{2+}$ influx through synaptic NMDARs leads to the activation and nuclear translocation of ERK followed by phosphorylation of the neuroprotection-associated transcription factor, CREB, and transcription of prosurvival gene products including the prosurvival neurotrophic factor BDNF. Synaptic NMDAR activity also induces the nuclear export of HDACs and of the proapoptotic transcription factor FOXO. Export of HDACs allows for the acetylation and disinhibition of transcription mediated by prosurvival transcription factors such as MEF2 and CREB. Conversely, ES-NMDAR-mediated $\mathrm{Ca}^{2+}$ entry triggers transcription of the proapoptotic $\mathrm{Ca}^{2+}$-activated chloride channel Clcal, triggers the rapid dephosphorylation and inactivation of ERK, thus preventing its nuclear translocation, interferes with the nuclear export of HDACs, and triggers the rapid nuclear import of FOXO proteins. Thus, whereas activation of synaptic NMDARs promotes the transcription of neuroprotective target genes via CREB and MEF2, ES-NMDAR activation actively represses CREB- and MEFdependent gene transcription, and leads to the transcription of genes associated with neuronal degeneration and apoptotic cell death. 
A.M. Hagenston and $\mathrm{H}$. Bading

showed intact cytoplasmic $\mathrm{Ca}^{2+}$ transients, but significantly reduced nuclear $\mathrm{Ca}^{2+}$ signals in response to stimulation of plasma membrane $\mathrm{Ca}^{2+}$ channels. Analysis of transcriptional responses subsequently revealed that the reduction in nuclear $\mathrm{Ca}^{2+}$ signaling could be specifically linked to an inhibition of CREB-dependent gene transcription. In contrast, TCF/SRF-dependent gene transcription was shown to be contingent only on the generation of $\left[\mathrm{Ca}^{2+}\right]_{\mathrm{i}}$ increases in the cytoplasm (Hardingham et al. 1997). A follow-up study subsequently unveiled a critical role for nuclear $\mathrm{Ca}^{2+}$ in CREB-dependent gene transcription stimulated by the activity of synaptic NMDARs in neurons (Hardingham et al. 2001b).

How does nuclear $\mathrm{Ca}^{2+}$ support synaptic NMDAR-mediated signaling to CREB? Synaptic activity-dependent signaling to $\mathrm{CREB}$ is achieved primarily via two different $\mathrm{Ca}^{2+}$ dependent kinase cascades: the CaMK and the Ras/MAPK pathways (Chawla et al. 1998; Hardingham et al. 1999). Although both pathways cause phosphorylation of CREB on its activator site serine 133, additional stimulation of CBP, a transcriptional coactivator that interacts with phosphorylated CREB, is also crucial for the induction of CREB-mediated transcription (Chawla et al. 1998; Hu et al. 1999; Impey et al. 2002). The induction of CBP, in turn, critically depends on CaMKIV, the activation of which can be achieved by an increase in nuclear $\left[\mathrm{Ca}^{2+}\right]_{\mathrm{i}}$ (Chawla et al. 1998; Hardingham et al. 1999; Impey et al. 2002). CREB-mediated transcription triggered by synaptic NMDARs thus necessitates convergence of the Ras/MAPK signaling cascade with a nuclear $\mathrm{Ca}^{2+}$ - and CaMKIV-dependent signal to CBP. It follows that the presence or absence of nuclear $\left[\mathrm{Ca}^{2+}\right]_{\mathrm{i}}$ increases during up-regulated NMDARdependent Ras/MAPK signaling has the capacity to determine whether these may induce CREB-mediated gene transcription. Nuclear $\mathrm{Ca}^{2+}$ signaling is thus a critical determinant of whether the activation of synaptic NMDARs leads to solely TCF/SRF-, or both TCF/SRFand CREB-dependent transcription (see Fig. 2) (Hardingham et al. 1997, 2001a,b; Chawla et al. 1998).
It has been proposed that $\left[\mathrm{Ca}^{2+}\right]_{\mathrm{i}}$ increases must originate at synapses to trigger neuronal activity-dependent CREB-mediated transcriptional responses (Murphy et al. 1991; Deisseroth et al. 1996). An important point therefore is that CaMKIV, which resides in the nucleus, not only is necessary for the activation of CBP, but can also phosphorylate CREB. Consequently, nuclear $\mathrm{Ca}^{2+}$ signaling to CaMKIV is sufficient to induce gene transcription via CREB (Hardingham et al. 2001b). The duration of nuclear $\left[\mathrm{Ca}^{2+}\right]_{\mathrm{i}}$ increases, a feature which correlates with the duration of CBP activation and CREB phosphorylation, is an important factor for determining the magnitude of genomic responses (Bito et al. 1996; Chawla and Bading 2001; Hardingham et al. 2001b). It would therefore seem that — whether arising from synaptic NMDARs, L-type VDCCs, or intracellular $\mathrm{Ca}^{2+}$ stores-any $\mathrm{Ca}^{2+}$ signal that invades the nucleus and is of sufficient duration and magnitude to stimulate CaMKIV, may likewise be sufficient to trigger CREB-mediated gene transcription.

An additional means by which nuclear $\mathrm{Ca}^{2+}$ can regulate genomic responses is via a direct interaction with the transcriptional repressor DREAM. DREAM is a $\mathrm{Ca}^{2+}$ - and DNA-binding protein that inhibits gene transcription by restricting the access of stimulatory transcription factors like CREB to their DNA-binding domains (Carrion et al. 1999; Ledo et al. 2002). Binding of $\mathrm{Ca}^{2+}$ to DREAM allows it to dissociate from its DNA binding site (Carrion et al. 1999; Ledo et al. 2000, 2002). Thus, nuclear $\mathrm{Ca}^{2+}$ acting through DREAM can function as a signal for transcriptional disinhibition. New research implicates DREAM also in synaptic plasticity and memory consolidation. For example, DREAM knockout mice show enhanced CREB-dependent gene transcription, enhanced LTP, and improved performance in a variety of behavioral assays for transcription-dependent long-term memory (Lilliehook et al. 2003; Alexander et al. 2009; Fontan-Lozano et al. 2009). Notably, these mice continued to show improved memory formation during aging, and were found to manifest a marked decrease in aging-associated 
pathological changes in the hippocampus (Fontan-Lozano et al. 2009). Moreover, using electrophoretic mobility shift assays with hippocampal nuclear extracts, it was observed that DREAM binding to DNA decreased following training on a hippocampus-dependent behavioral task (Fontan-Lozano et al. 2009). These findings underline the critical involvement of nuclear $\mathrm{Ca}^{2+}$-dependent control of genomic responses through direct interactions with transcriptional regulators like DREAM in the coupling of excitatory stimuli to memory formation and cognitive functioning.

\section{EPIGENETIC MECHANISMS IN SYNAPTIC ACTIVITY AND $\mathrm{Ca}^{2+}$-DEPENDENT TRANSCRIPTIONAL REGULATION}

Chromatin remodeling is now emerging as a powerful means by which synaptic activity and intracellular $\mathrm{Ca}^{2+}$ signaling can induce genomic responses (Fig. 5). Dynamic changes in chromatin structure are brought about by an array of histone posttranslational modifications including phosphorylation, methylation, and acetylation. These changes are implicated in gene transcription, synaptic plasticity, memory consolidation, and neuronal survival (Alarcon et al. 2004; Korzus et al. 2004; Jiang et al. 2006; Oliveira et al. 2007; Lubin et al. 2008; Koshibu et al. 2009), and their dysregulation is causatively linked to both developmental and neurodegenerative disorders (Petrij et al. 1995; Jorgensen and Bird 2002; Alarcon et al. 2004; Jiang et al. 2006; Zhou et al. 2006; Fischer et al. 2007; Duclot et al. 2010).

Histone acetylation, which results in chromatin expansion and increased access to transcription factor binding sites, is controlled by histone acetyltransferases (HATs) and HDACs. One of the means by which neuronal activitydependent $\mathrm{Ca}^{2+}$ signaling can influence transcription factor activity is through the dynamic regulation of these enzymes. For example, synaptic activity-dependent $\left[\mathrm{Ca}^{2+}\right]_{\mathrm{i}}$ increases act through CaMKIV to stimulate CBP, a CREB coactivator and HAT that interacts with numerous transcription factors (Chawla et al. 1998; Sterner and Berger 2000; Impey et al. 2002;
Bedford et al. 2010). In a similar vein, NMDARmediated $\mathrm{Ca}^{2+}$ signaling through the Ras/ MAPK pathway may stimulate gene transcription via p300, a CBP analog HAT (Sterner and Berger 2000; Legube and Trouche 2003; Li et al. 2003; Oliveira et al. 2006, 2007; Bedford et al. 2010). Synaptic activation of NMDARs and L-type VDCCs shapes transcriptional responses also by triggering the CaMK-dependent nuclear export of the class II HDAC and MEF2 corepressor, HDAC5, an effect that is blocked either by costimulation of ESNMDARs or by pharmacological induction of cyclic AMP signaling (McKinsey et al. 2000; Chawla et al. 2003; Belfield et al. 2006). These and other findings suggest that transcription factor phosphorylation and histone acetylation may represent parallel targets of synapse-tonucleus $\mathrm{Ca}^{2+}$-dependent signaling through the CaMK and Ras/MAPK pathways. Indeed, a number of recent studies have established CBP-, p300-, CaMK-, and/or NMDAR/Ras/ MAPK-dependent histone modifications as critical regulatory mechanisms controlling the synaptic plasticity gene BDNF, the induction of LTP, and the consolidation of memory (Hardingham et al. 1999; Impey et al. 2002; Chawla et al. 2003; Chwang et al. 2006, 2007; Oliveira et al. 2006, 2007; Wood et al. 2006; Chandramohan et al. 2008; Brami-Cherrier et al. 2009; Tian et al. 2009, 2010a,b; Duclot et al. 2010).

Synaptic activity and $\mathrm{Ca}^{2+}$-dependent regulation of gene expression may further be achieved via the modulation of cofactors that facilitate the association of HATs and HDACs with DNA. An example is methyl-CpG binding protein 2 (MeCP2), a transcriptional regulator that has been shown to suppress gene expression by recruiting HDAC-containing protein complexes to the genome (Jones et al. 1998; Nan et al. 1998; Jorgensen and Bird 2002; Chen et al. 2003; Martinowich et al. 2003; Zhou et al. 2006; Tao et al. 2009). Synaptic activity and $\mathrm{Ca}^{2+}$-dependent regulation of $\mathrm{MeCP} 2$ can be accomplished via its phosphorylation by CaMKs (Zhou et al. 2006; Tao et al. 2009). In particular, the $\mathrm{Ca}^{2+}$-dependent phosphorylation of MeCP2 has been shown both to trigger transcriptional derepression of known 
A.M. Hagenston and H. Bading

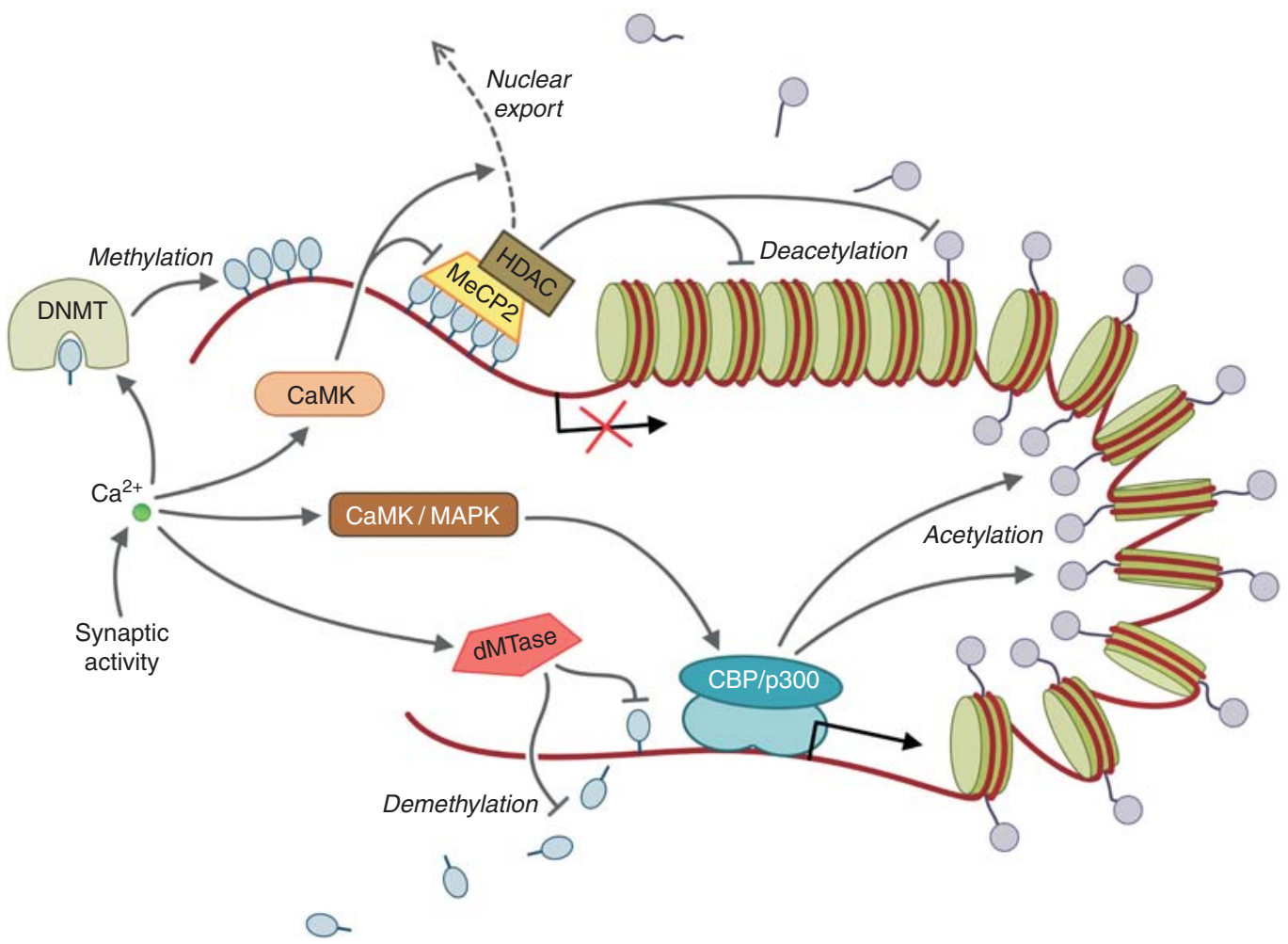

Figure 5. Epigenetic mechanisms in synaptic activity and $\mathrm{Ca}^{2+}$-dependent transcriptional regulation. Synaptic activity-dependent $\left[\mathrm{Ca}^{2+}\right]_{\mathrm{i}}$ increases may influence chromatin structure-and therewith access of transcription factors and regulatory enzymes to their specific interaction domains - through influences on histone acetylation and DNA methylation. Synaptic activity-dependent $\mathrm{Ca}^{2+}$ signals acting through CaM and CAMK and Ras/ MAPK signaling cascades can, for instance, activate HATs such as CBP and p300. These transcriptional coactivators catalyze the posttranslational acetylation of histones, leading to chromatin relaxation, increased access of transcription factors to their respective DNA binding domains, and up-regulation of gene transcription in affected genomic regions. Alternately, nuclear $\mathrm{Ca}^{2+}$ increases associated with synaptic activity may trigger the CAMK-dependent phosphorylation and dissociation of methyl CpG- binding proteins like MeCP2 from methylated sequences of DNA as well as the nuclear export of the HDACs with which they interact. HDAC activity results in the deacetylation of histones and the subsequent compression of chromatin, leading to a suppression of transcriptional activity. MeCP2 dissociation and HDAC export thus induce a derepression of gene transcription. $\mathrm{Ca}^{2+}$ influx associated with synaptic activity is linked also to de novo DNA methylation via DNMTs such as DNMT3a, and to active DNA demethylation via dMTases such as GADD45a. Note that, although not shown here, histone phosphorylation, ubiquitination, and methylation also contribute to the epigenetic regulation of gene expression (Levenson and Sweatt 2006), and may likewise be involved in $\mathrm{Ca}^{2+}$-dependent synapseto-nucleus communication.

plasticity-associated genes via a mechanism that involves its dissociation from the genome followed by an up-regulation of histone acetylation (Chen et al. 2003; Martinowich et al. 2003; Zhou et al. 2006; Tao et al. 2009) and to activate gene transcription by recruiting transcription factors such as CREB1 to the genome (Chahrour et al. 2008).
An additional mechanism by which synaptic activity and associated $\left[\mathrm{Ca}^{2+}\right]_{\mathrm{i}}$ increases might stimulate the genomic responses required for neuronal activity-induced acquired neuroprotection, synaptic plasticity, and long-term memory is via the dynamic regulation of DNA methylation (Levenson et al. 2006; Barreto et al. 2007; Miller and Sweatt 2007; Zhang 
et al. 2007b, 2009; Lubin et al. 2008; Miller et al. 2008, 2010; Feng et al. 2010). De novo DNA methylation mediated by DNA methyltransferases (DNMTs) such as DNMT3a has, for instance, been shown to have a critical function in the molecular signaling cascades that underlie synaptic plasticity and memory formation (Levenson et al. 2006; Feng et al. 2010). Moreover, it has been reported that LTP-inducing stimulation in vitro and fear conditioning training in vivo induce rapid methylation changes in the promoter regions of specific plasticity regulated genes such as protein phosphatase 1, brain-derived neurotrophic factor, and reelin (Martinowich et al. 2003; Miller and Sweatt 2007; Lubin et al. 2008). Importantly, pharmacological disruption of $\mathrm{Ca}^{2+}$ signaling via NMDARs or of DNMTs was observed not only to compromise the induction of LTP and the consolidation of long-term memory but also to block stimulus-induced methylation changes (Levenson et al. 2006; Miller and Sweatt 2007; Lubin et al. 2008; Miller et al. 2008, 2010). In combination with the recent identification of growth arrest and DNA damage inducible protein $45 \alpha(\mathrm{GADD} 45 \alpha)$, a putative stressinduced nuclear DNA demethylase (DMTase) reported to relieve gene silencing by erasing methylation marks (Barreto et al. 2007; Rai et al. 2008; Ma et al. 2009), as a target of synaptic activity-dependent nuclear $\mathrm{Ca}^{2+} / \mathrm{CaM}$ signaling (Zhang et al. 2007a, 2009), these findings suggest that $\mathrm{Ca}^{2+}$ may indeed participate in the regulation of DNA methylation. Clearly, much work remains in identifying the particular signaling pathways linking neuronal activitydependent $\left[\mathrm{Ca}^{2+}\right]_{\mathrm{i}}$ increases to dynamic DNA methylation and chromatin remodeling. We nonetheless anticipate that this developing field will yield many exciting and important insights into the mechanisms underlying synapse-tonucleus communication.

\section{$\mathrm{Ca}^{2+}$ REGULATION OF NUCLEAR PORE PERMEABILITY}

Next to its function as a second messenger in the governance of neuronal activity-dependent genomic responses, $\mathrm{Ca}^{2+}$ entering the nucleus may have the added function of regulating nuclear permeability to second messengers. Nucleocytoplasmic transport of soluble molecules takes place at the nuclear pore, a large macromolecular complex consisting of eight ion channels and a large central passage (Akey 1989; Otis et al. 2006). Passage of molecules through this complex depends both on size and on the presence or absence of appropriate localization sequences that enable interaction with nuclear importing proteins. Accordingly, molecules larger in size than $40-60 \mathrm{kD}$ need a signaling sequence to cross the nuclear envelope, and molecules smaller than $4-10 \mathrm{kD}$ diffuse freely between cytosol and nucleus. Intermediate-sized molecules $(10-40 \mathrm{kD})$ do not require a targeting signal, although their passage may be regulated at the level of the nuclear pore (reviewed in O'Brien et al. 2007). Two $\mathrm{Ca}^{2+}$-dependent mechanisms have been proposed for such regulation. On one hand, the filling state of the nuclear lumen, which is contiguous with the ER lumen, may influence the size of the nuclear pore. Accordingly, depletion of nuclear $\mathrm{Ca}^{2+}$ stores in a variety of cell types has been shown to induce a conformational change of the nuclear pore complex such that it excludes molecules greater in size than approximately $10 \mathrm{kD}$ (Greber and Gerace 1995; Stehno-Bittel et al. 1995; Perez-Terzic et al. 1999; Wang and Clapham 1999; Erickson et al. 2006; Stoffler et al. 2006). Alternately, a recent study suggests that $\mathrm{Ca}^{2+}$ may alter nuclear permeability cytoplasmically: stimulation of $\mathrm{G}_{\mathrm{q} / 11 \text {-coupled receptors and subsequent }}$ internal $\mathrm{Ca}^{2+}$ release were shown to rapidly and briefly increase nuclear permeability in a liver cell line (O'Brien et al. 2007). Interestingly, this increase in permeability-for which an increase in $\left[\mathrm{Ca}^{2+}\right]_{\mathrm{i}}$ near the nuclear envelope was both necessary and sufficientwas unidirectional from cytosol to nucleus. These findings raise the very intriguing possibility that, in addition to regulating genomic responsiveness via interactions with nuclearly localized effectors, somatonuclear $\mathrm{Ca}^{2+}$ signals may simultaneously promote the facilitated diffusion of second messengers into the nucleus. 
A.M. Hagenston and H. Bading

\section{GENERATING NUCLEAR $\mathrm{Ca}^{2+}$ SIGNALS}

With respect to the generation of nuclear $\mathrm{Ca}^{2+}$ signals, it is important to note that the nuclear envelope does not present a spatial barrier for the transmission of $\mathrm{Ca}^{2+}$ transients between somatic and nuclear compartments (Danker et al. 2001; Shahin et al. 2001; Eder and Bading 2007). Cytoplasmic $\left[\mathrm{Ca}^{2+}\right]_{\mathrm{i}}$ increases that reach the nuclear envelope are thus poised to participate in nuclear $\mathrm{Ca}^{2+}$. dependent transcriptional regulation. Likely the most obvious candidates for generating robust nuclear $\mathrm{Ca}^{2+}$ signals are L-type VDCCs (Fig. 3B). In fact, somatic action potentials, which generate robust L-type VDCC-mediated $\mathrm{Ca}^{2+}$ transients in the cytoplasm and nucleus (Johenning and Holthoff 2007), have been reported to induce CREB phosphorylation, CREB-dependent up-regulated gene expression, and transcription-dependent synaptic plasticity (Dudek and Fields 2002). Investigations aimed at identifying specific $\mathrm{Ca}^{2+}$ sources involved in the induction of synaptic plasticity also point to L-type VDCCs and somatic $\mathrm{Ca}^{2+}$ increases specifically as critical mediators of transcription-dependent plasticity (Raymond and Redman 2002, 2006). By way of their subcellular localization on neuronal somata and proximal dendrites, these channels are appropriately positioned to generate robust somatonuclear $\left[\mathrm{Ca}^{2+}\right]_{\mathrm{i}}$ increases in response to neuronal activity-dependent depolarizations of the plasma membrane (Westenbroek et al. 1990; Obermair et al. 2004; Leitch et al. 2009). Interestingly, the activation kinetics of L-type channels has been suggested to enable their preferred responsiveness to trains of EPSPs over action potentials (Mermelstein et al. 2000; Liu et al. 2003). This proposed ability of L-type VDCCs to discriminate between different forms of depolarizing stimuli could explain why synaptic activity has been observed to be more effective in causing $\mathrm{Ca}^{2+}$-dependent CREB phosphorylation than action potentials alone (Deisseroth et al. 1996; Mermelstein et al. 2000), and suggests that L-type channels on the somatic membrane might contribute to synapse-to-nucleus communication in the form of a synaptic activity-dependent nuclear $\mathrm{Ca}^{2+}$ signal.

Another particularly interesting candidate for the $\mathrm{Ca}^{2+}$-dependent conveyance of information between synapse and nucleus is mGluRmediated, $\mathrm{IP}_{3} \mathrm{R}$-dependent $\mathrm{Ca}^{2+}$ release from intracellular stores (Fig. 3C). $\mathrm{IP}_{3} \mathrm{R}$-dependent internal $\mathrm{Ca}^{2+}$ release has been implicated in CREB-mediated gene transcription (Hardingham et al. 2001b; Hu et al. 2002; Carrasco et al. 2004; Mao et al. 2008) as well as in the long-term potentiation and depression of synaptic strength, the stimulation of neurite outgrowth, and the activation of trophic and apoptotic signaling cascades (Berridge 1998; Verkhratsky and Petersen 1998; Korkotian and Segal 1999; Yeckel et al. 1999; Berridge et al. 2000; Rose and Konnerth 2001; Vanderklish and Edelman 2002; Raymond and Redman 2006). Neuronal $\left[\mathrm{Ca}^{2+}\right]_{i}$ increases caused by the release of $\mathrm{Ca}^{2+}$ from $\mathrm{IP}_{3}$-sensitive intracellular stores are unique when compared to $\left[\mathrm{Ca}^{2+}\right]_{\mathrm{i}}$ increases generated by VDCC- or NMDARdependent $\mathrm{Ca}^{2+}$ influx in a number of important ways. Perhaps the most notable of these is the ability of internal $\mathrm{Ca}^{2+}$ release to propagate as a wave from its dendritic site of initiation to distant regions of the neuron including the soma and nucleus (Jaffe and Brown 1994; Pozzo-Miller et al. 1996; Power and Sah 2002, 2007; Larkum et al. 2003; Watanabe et al. 2006; Hagenston et al. 2008). These waves of $\mathrm{Ca}^{2+}$ release are predominantly observed in the primary apical dendrites of pyramidal neurons, in which they regularly cover distances upward of $50 \mu \mathrm{m}$ (Nakamura et al. 1999, 2002; Power and Sah 2007; Hagenston et al. 2008). In contrast, $\left[\mathrm{Ca}^{2+}\right]_{\mathrm{i}}$ increases resulting from NMDAR activation are predominantly observed in highly spinous apical oblique and basal dendrites, and are almost negligible in the primary apical dendrite or soma (Schiller et al. 2000; Nakamura et al. 2002; Raymond and Redman 2006). Moreover, $\mathrm{Ca}^{2+}$ waves can regularly attain amplitudes of up to $10 \mu \mathrm{M}$, approximately 5 - to 15 -fold greater than $\left[\mathrm{Ca}^{2+}\right]_{\mathrm{i}}$ increases evoked by trains of action potentials (Nakamura et al. 1999; Power and Sah 2002, 2007; Larkum et al. 2003). Additionally, 
whereas VGCC- and NMDAR-associated $\left[\mathrm{Ca}^{2+}\right]_{\mathrm{i}}$ increases turn on at the start of a stimulus or spike train and typically begin to decay at the end of that train (Pozzo-Miller et al. 1996), the rising phase of synaptically activated $\mathrm{Ca}^{2+}$ release generally initiates with a delay of tens to hundreds of milliseconds, can easily outlast the duration of synaptic stimulation, and may even be as great as hundreds of milliseconds in any one location (Pozzo-Miller et al. 1996; Kapur et al. 2001; Larkum et al. 2003; Power and Sah 2007). The decay of release-associated $\left[\mathrm{Ca}^{2+}\right]_{\mathrm{i}}$ transients is similarly prolonged, presumably because of the slow inactivation kinetics of the $\mathrm{IP}_{3}$ receptor (Li et al. 1995; Taylor 1998; Foskett et al. 2007). Thus, the total duration of internal $\mathrm{Ca}^{2+}$ release-associated $\left[\mathrm{Ca}^{2+}\right]_{\mathrm{i}}$ increases is typically on the order of hundreds of milliseconds to longer than one second (Nakamura et al. 1999; Larkum et al. 2003). In sum, mGluR-mediated $\mathrm{IP}_{3} \mathrm{R}$-dependent $\mathrm{Ca}^{2+}$ waves have the combined characteristics of large amplitude, long duration, and ability to propagate long distances along the primary apical dendrite into the soma and nucleus. These features make $\mathrm{Ca}^{2+}$ waves ideally suited to evoke large, long-lasting nuclear $\mathrm{Ca}^{2+}$ signals and robust transcriptional responses in response to synaptic activity (Chawla and Bading 2001; Power and Sah 2002, 2007; Hagenston et al. 2008).

Under what conditions are $\mathrm{Ca}^{2+}$ waves likely to play a role in nuclear $\mathrm{Ca}^{2+}$ signaling? Investigations of $\mathrm{IP}_{3} \mathrm{R}$ function in reduced cellular and bilayer preparations, modeling studies, and examinations of $\mathrm{Ca}^{2+}$ waves in nonneuronal cells describe a number of possible influences on the extent of $\mathrm{Ca}^{2+}$ wave propagation (e.g., Parker and Ivorra 1990; Bezprozvanny et al. 1991; Bootman et al. 1997; Callamaras et al. 1998; Verkhratsky and Petersen 1998; Solovyova and Verkhratsky 2002; Friel 2004; Foskett et al. 2007). These include $\left[\mathrm{Ca}^{2+}\right]_{\mathrm{i}}$ at the time of $\mathrm{IP}_{3} \mathrm{R}$ activation by $\mathrm{IP}_{3}$, the concentration and distribution of mobilized $\mathrm{IP}_{3}$ in the cytosol, the size of the readily releasable $\mathrm{ER} \mathrm{Ca}^{2+}$ pool, and the biophysical state of $\mathrm{IP}_{3} \mathrm{Rs}$. These potential influences translate into a number of different factors likely to regulate the propagation of
mGluR-mediated, $\mathrm{IP}_{3} \mathrm{R}$-dependent $\mathrm{Ca}^{2+}$ waves toward and into the somata of neurons, many of which have been validated by $\mathrm{Ca}^{2+}$ imaging data in neurons. These factors include the generation of action potentials and VDCCdependent $\left[\mathrm{Ca}^{2+}\right]_{\mathrm{i}}$ increases coincident with $\mathrm{IP}_{3}$-mobilizing stimuli (Nakamura et al. 1999; Yamamoto et al. 2000; Larkum et al. 2003; Hagenston et al. 2008), the number and distribution of activated synapses and the activity of neuromodulatory $\mathrm{G}$ protein-coupled receptors linked to $\mathrm{IP}_{3}$ generation (Lezcano and Bergson 2002; Nakamura et al. 2002; Tang et al. 2003; Watanabe et al. 2006; Dai et al. 2008; Hagenston et al. 2008; Fitzpatrick et al. 2009), the activity history of stimulated neurons (Jaffe and Brown 1994; Pozzo-Miller et al. 1996; Morikawa et al. 2000; Rae et al. 2000; Larkum et al. 2003; Stutzmann et al. 2003; Gulledge and Stuart 2005; Power and Sah 2005; Hong and Ross 2007; Hagenston et al. 2008), and the balance of activated kinases and phosphatases that target the $\mathrm{IP}_{3} \mathrm{R}$. Protein kinase A in particular is promising in this respect, as its activity is linked not only to $\mathrm{IP}_{3} \mathrm{R}$ phosphorylation, but also to increased $\mathrm{IP}_{3} \mathrm{R}$ sensitivity to $\mathrm{IP}_{3}$ and to augmented internal $\mathrm{Ca}^{2+}$ release (Wojcikiewicz and Luo 1998; Bugrim 1999; Tang et al. 2003; Patterson et al. 2004; Straub et al. 2004; Bezprozvanny 2005; Foskett et al. 2007; AM Hagenston and M Yeckel, unpubl.). Following from these studies, we predict that $\mathrm{IP}_{3} \mathrm{R}$-dependent $\mathrm{Ca}^{2+}$ waves are most likely to contribute to nuclear $\mathrm{Ca}^{2+}$ signaling when elicited by the robust and simultaneous activation of synapses on many proximal apical oblique branches during and/or following a train of action potentials, and particularly when protein kinase A signaling to $\mathrm{IP}_{3} \mathrm{Rs}$ has been engaged.

An additional mechanism has recently emerged by which synaptic activity may give rise to nuclear $\left[\mathrm{Ca}^{2+}\right]_{\mathrm{i}}$ increases. This means of synapse-to-nucleus communication involves the import of glutamate through excitatory amino acid transporters (EAATs) and the subsequent activation of mGluRs located on the inner nuclear membrane (Fig. 1) (O'Malley et al. 2003; Jong et al. 2005, 2007; Sheldon and Robinson 2007; Kumar et al. 2008). More 
A.M. Hagenston and $\mathrm{H}$. Bading

specifically, synaptically released glutamate is proposed to be transported by extra- and perisynaptic EAATs into the cytosol and diffuse to the cell soma, in which it is transported by nuclear EAATs into the nuclear lumen. There it binds to and activates nuclear resident mGluRs, leading to the liberation of $\mathrm{IP}_{3}$ into the nucleus where it can bind $\mathrm{IP}_{3} \mathrm{Rs}$ on the inner nuclear envelope. Thus, glutamate uptake at the synapse is proposed to give rise to $\mathrm{Ca}^{2+}$ release from the nuclear lumen directly into the nucleus (O'Malley et al. 2003; Jong et al. 2005, 2007; Sheldon and Robinson 2007; Kumar et al. 2008). This model is bolstered by data documenting the presence and functional responsiveness of EAATs, mGluRs, and $\mathrm{IP}_{3}$ Rs on the inner nuclear membranes of a variety of cell types including dissociated neurons (Humbert et al. 1996; Echevarria et al. 2003; Gerasimenko et al. 2003; O'Malley et al. 2003; Jong et al. 2005, 2007; Marchenko et al. 2005; Quesada and Verdugo 2005; Marchenko and Thomas 2006; Sheldon and Robinson 2007; Kumar et al. 2008; Bootman et al. 2009; Rodrigues et al. 2009). It remains to be seen, however, whether and under which conditions internal $\mathrm{Ca}^{2+}$ release mediated by intranuclear mGluRs and $\mathrm{IP}_{3} \mathrm{Rs}$ can be evoked in intact brain tissue. One possibility is that particularly robust stimulus trains such as those known to induce LTP lead to spillover of glutamate, which is then taken up by perisynaptic and extrasynaptic EAATs and shuttled to the nucleus. Subsequent intranuclear $\mathrm{Ca}^{2+}$ release might act to ensure the generation of a $\mathrm{Ca}^{2+}$ signal concomitant with the import of synaptically activated second messengers. As such, this pathway could support NMDAR- and Ras/MAPK-mediated stimulation of CREB-dependent transcription, synaptic plasticity, and neuronal activitydependent neuroprotection. Alternatively, this proposed signaling pathway to the nucleus might be most robustly induced when extrasynaptic glutamatergic signaling is elevated. As such, it could contribute to the genomic responses and prodeath activity associated with ES-NMDAR activation, ischemia, and seizure (Hardingham et al. 2002; Liu et al. 2007; SierraParedes and Sierra-Marcuno 2007; Zhang et al. 2007b; Leveille et al. 2008; Scimemi et al. 2009; Wahl et al. 2009).

\section{THE ENDOPLASMIC RETICULUM AS A CONDUIT FROM SYNAPSE TO NUCLEUS}

ER in neurons, the "neuron within a neuron," forms a continuous network that extends into all parts of the cell from the nuclear envelope to the most distal dendritic and axonal processes (Berridge 1998). In addition to enabling the propagation of $\mathrm{Ca}^{2+}$ waves over long distances in the dendrites and soma, this ubiquitous distribution of ER may allow for postsynaptic signal propagation either via the diffusion of second messengers embedded in or attached to its membranes (Jordan and Kreutz 2009) or in the form of rapid intraluminal $\mathrm{Ca}^{2+}$ redistributions within and between dendritic and somatonuclear compartments (Park et al. 2000, 2008; Choi et al. 2006). This latter transit system, which is called $\mathrm{Ca}^{2+}$ tunneling, has been credited with the ability of dendrites and spines sparse in ER to persistently respond to repetitive $\mathrm{Ca}^{2+}$ mobilizing inputs (Park et al. 2000; Choi et al. 2006). Conversely, ER $\mathrm{Ca}^{2+}$ tunneling is suggested to result in depletion of the somatonuclear internal store following strong and long-lasting stimulation of $\mathrm{Ca}^{2+}$ release in multiple dendritic compartments (Choi et al. 2006; Park et al. 2008). In view of the influence exerted by luminal $\mathrm{Ca}^{2+}$ on nuclear pore permeability (Greber and Gerace 1995; Stehno-Bittel et al. 1995; Lee et al. 1998; Danker et al. 2001), $\mathrm{IP}_{3} \mathrm{R}$ activity (Missiaen et al. 1992; Bezprozvanny and Ehrlich 1994; Thrower et al. 2000), and the driving force of $\mathrm{Ca}^{2+}$ ions leaving the ER (e.g., Solovyova et al. 2002), and of the potential for somatonuclear internal $\mathrm{Ca}^{2+}$ release to regulate CaMKIV activity and nuclear pore permeability, such a signal could have important consequences for the regulation of gene expression programs.

A recent study introduces another particularly intriguing ER-dependent mechanism by which signals may be transmitted from synapse to nucleus: as passively propagating electrotonic potentials along ER membranes (Fig. 3D) (Shemer et al. 2008). This proposal is grounded 
on the basis that, like the plasma membrane, the ER membrane is an effective charge separator and may thus support the generation and propagation of trans-ER depolarizations and hyperpolarizations. Such potential fluctuations are likely to occur at ER in synaptic spines and dendrites either as a result of capacitative conduction of plasma membrane potential fluctuations combined with $\mathrm{Ca}^{2+}$ uptake into the ER via sarcoendoplasmic reticulum $\mathrm{Ca}^{2+}$ ATPases, or as a consequence of the release of $\mathrm{Ca}^{2+}$ via RyRs and $\mathrm{IP}_{3} \mathrm{Rs}$ localized to spines and dendrites. Alternately, ER potentials may be evoked in the soma during action potentials and in response to internal $\mathrm{Ca}^{2+}$ release. Using a computational "cable in cable" model, it was shown that electrotonic potentials across the ER-and associated current flow within the ER-can be rapidly and effectively transmitted both from synapse to soma, and from the soma into the dendritic arbor (Shemer et al. 2008). Significantly, the investigators observe that these two modes of signal propagation have opposite effects on the transmembrane potential across the nuclear envelope and suggest on this basis that electrotonic signal propagation along ER membranes may account for the ability of the nucleus to differentiate between synaptic signals originating at dendritic spines and backpropagating action potentials generated in the soma (Shemer et al. 2008). That said, it remains to be determined what the specific consequences of nuclear envelope depolarizations or hyperpolarizations might be. One possible scenario involves the activation of putative intracellular voltage-dependent cation channels (Schmid et al. 1990; Martin and Ashley 1993; Mazzanti et al. 2001; Bkaily et al. 2009; Matzke et al. 2010). Alternatively, nuclear envelope depolarizations may regulate signaling proteins that have been proposed to lead to intranuclear $\mathrm{IP}_{3}$ mobilization (Billups et al. 2006; Ryglewski et al. 2007; Bootman et al. 2009; Liu et al. 2009; see above). Among other possibilities, changes in nuclear potential might also modulate nuclear pore permeability (Matzke and Matzke 1991; Mazzanti et al. 2001; Matzke et al. 2010). Although these possible consequences of a changing nuclear potential remain to be tested, their potential to influence nuclear $\mathrm{Ca}^{2+}$ signaling and neuronal activity-dependent gene transcription nonetheless makes the conduction and summation of electrotonic potentials along ER and nuclear membranes a compelling prospective route for synapse-tonucleus communication.

\section{CONCLUDING REMARKS}

We have attempted here to provide a brief overview of the means by which synaptic excitation may be conveyed to the nucleus to influence neuronal activity-dependent gene transcription, particularly as it relates to synaptic plasticity, learning and memory, and neuronal survival and death processes. Just as the findings we describe inform our understanding of basic neuronal functions and functional responses, so too do they serve the greater aims of neuroscience and cellular signaling research to unravel the causes of neurocognitive disorders and to provide direction for the eventual development of possible therapeutic interventions. Indeed, dysregulations of the many of the proteins and processes involved in the generation of neuronal activity-dependent genomic responses we have described here have already been implicated in a wide range of psychiatric, developmental, and neurodegenerative disorders, including schizophrenia, depression, drug addiction, Rett syndrome, fragile $\mathrm{X}$ mental retardation, Alzheimer's disease, Huntington's disease, and ischemic stroke (Hong et al. 2005; Tsankova et al. 2007; Abel and Zukin 2008; Cohen and Greenberg 2008; Graff and Mansuy 2009; Kramer and van Bokhoven 2009; Reichenberg et al. 2009). Given the importance of nuclear calcium for the health of neurons and their ability to undergo activity-induced adaptations, a dysfunction in the generation of calcium transients and/or propagation to the nucleus (termed "nuclear calciopathy"; Zhang et al. 2011) may be a common denominator of both cognitive impairments and neurodegenerative processes. Thus, just as we are motivated to continue developing a more complete understanding of intracellular $\mathrm{Ca}^{2+}$ signaling and its role in the dialog between synapse and nucleus, 
A.M. Hagenston and $\mathrm{H}$. Bading

so too can we be driven by the knowledge that our findings may lead the way to an improved understanding of those changes responsible for the altered emotional and conceptual responses that define mental illness, the impaired learning and memory that accompanies developmental cognitive disorders, and the cell death associated with neurodegenerative diseases.

\section{ACKNOWLEDGMENTS}

We wish to thank A.M. Oliveira for helpful discussions during the preparation of this manuscript. A.M.H. was supported by a postdoctoral fellowship from CellNetworksCluster of Excellence at the University of Heidelberg (EXC81). H.B. is a member of CellNetworks-Cluster of Excellence (EXC81), and was supported by the Alexander von Humboldt Foundation, the ERC Advanced Grant, the Deutsche Forschungsgemeinschaft, the EU Network of Excellence NeuroNE, and the EU Project GRIPANNT.

\section{REFERENCES}

Abel T, Zukin RS. 2008. Epigenetic targets of HDAC inhibition in neurodegenerative and psychiatric disorders. Curr Opin Pharmacol 8: 57-64.

Adachi M, Fukuda M, Nishida E. 1999. Two co-existing mechanisms for nuclear import of MAP kinase: Passive diffusion of a monomer and active transport of a dimer. EMBO J 18: 5347-5358.

Akey CW. 1989. Interactions and structure of the nuclear pore complex revealed by cryo-electron microscopy. J Cell Biol 109: 955-970.

Alarcon JM, Malleret G, Touzani K, Vronskaya S, Ishii S, Kandel ER, Barco A. 2004. Chromatin acetylation, memory, and LTP are impaired in $\mathrm{CBP}^{+/-}$mice: A model for the cognitive deficit in Rubinstein-Taybi syndrome and its amelioration. Neuron 42: 947-959.

Alexander JC, McDermott CM, Tunur T, Rands V, Stelly C, Karhson D, Bowlby MR, An WF, Sweatt JD, Schrader LA. 2009. The role of calsenilin/DREAM/KChIP3 in contextual fear conditioning. Learn Mem 16: 167-177.

Al-Mubarak B, Soriano FX, Hardingham GE. 2009. Synaptic NMDAR activity suppresses FOXO1 expression via a cis-acting FOXO binding site: FOXO1 is a FOXO target gene. Channels 3: 233-238.

Anderson KA, Means RL, Huang QH, Kemp BE, Goldstein EG, Selbert MA, Edelman AM, Fremeau RT, Means AR. 1998. Components of a calmodulin-dependent protein kinase cascade. Molecular cloning, functional characterization and cellular localization of $\mathrm{Ca}^{2+} /$ calmodulin-dependent protein kinase kinase $\beta$. J Biol Chem 273: 31880-31889.

Anderson KA, Noeldner PK, Reece K, Wadzinski BE, Means AR. 2004. Regulation and function of the calcium/ calmodulin-dependent protein kinase IV/protein serine/threonine phosphatase 2A signaling complex. J Biol Chem 279: 31708-31716.

Arnold FJ, Hofmann F, Bengtson CP, Wittmann M, Vanhoutte P, Bading H. 2005. Microelectrode array recordings of cultured hippocampal networks reveal a simple model for transcription and protein synthesis-dependent plasticity. J Physiol 564: 3-19.

Arundine M, Tymianski M. 2004. Molecular mechanisms of glutamate-dependent neurodegeneration in ischemia and traumatic brain injury. Cell Mol Life Sci 61: 657-668.

Bading H. 2000. Transcription-dependent neuronal plasticity the nuclear calcium hypothesis. Eur J Biochem 267: 5280-5283.

Bading H, Greenberg ME. 1991. Stimulation of protein tyrosine phosphorylation by NMDA receptor activation. Science 253: 912-914.

Bading H, Ginty DD, Greenberg ME. 1993. Regulation of gene expression in hippocampal neurons by distinct calcium signaling pathways. Science 260: 181-186.

Bading H, Segal MM, Sucher NJ, Dudek H, Lipton SA, Greenberg ME. 1995. N-methyl-D-aspartate receptors are critical for mediating the effects of glutamate on intracellular calcium concentration and immediate early gene expression in cultured hippocampal neurons. Neuroscience 64: 653-664.

Bading H, Hardingham GE, Johnson CM, Chawla S. 1997. Gene regulation by nuclear and cytoplasmic calcium signals. Biochem Biophys Res Commun 236: 541-543.

Bailey CH, Bartsch D, Kandel ER. 1996. Toward a molecular definition of long-term memory storage. Proc Natl Acad Sci 93: 13445-13452.

Bannister NJ, Larkman AU. 1995. Dendritic morphology of CA1 pyramidal neurones from the rat hippocampus: II. Spine distributions. J Comp Neurol 360: 161-171.

Barreto G, Schafer A, Marhold J, Stach D, Swaminathan SK, Handa V, Doderlein G, Maltry N, Wu W, Lyko F, et al. 2007. Gadd45a promotes epigenetic gene activation by repair-mediated DNA demethylation. Nature 445: $671-675$.

Beals CR, Clipstone NA, Ho SN, Crabtree GR. 1997. Nuclear localization of NF-ATc by a calcineurin-dependent, cyclosporin-sensitive intramolecular interaction. Genes Dev 11: 824-834.

Bedford DC, Kasper LH, Fukuyama T, Brindle PK. 2010. Target gene context influences the transcriptional requirement for the KAT3 family of CBP and p300 histone acetyltransferases. Epigenetics 5: 9-15.

Belfield JL, Whittaker C, Cader MZ, Chawla S. 2006. Differential effects of $\mathrm{Ca}^{2+}$ and cAMP on transcription mediated by MEF2D and cAMP-response element-binding protein in hippocampal neurons. J Biol Chem 281: 27724-27732.

Berridge MJ. 1998. Neuronal calcium signaling. Neuron 21: $13-26$. 
Berridge MJ, Lipp P, Bootman MD. 2000. The versatility and universality of calcium signalling. Nat Rev Mol Cell Biol 1: $11-21$.

Bezprozvanny I. 2005. The inositol 1,4,5-trisphosphate receptors. Cell Calcium 38: 261-272.

Bezprozvanny I. 2007. Inositol 1,4,5-tripshosphate receptor, calcium signalling and Huntington's disease. Subcell Biochem 45: 323-335.

Bezprozvanny I, Ehrlich BE. 1994. Inositol (1,4,5)-trisphosphate (InsP3)-gated Ca channels from cerebellum: Conduction properties for divalent cations and regulation by intraluminal calcium. J Gen Physiol 104: 821-856.

Bezprozvanny I, Watras J, Ehrlich BE. 1991. Bell-shaped calcium-response curves of Ins $(1,4,5) \mathrm{P} 3$ - and calciumgated channels from endoplasmic reticulum of cerebellum. Nature 351: 751-754.

Billups D, Billups B, Challiss RA, Nahorski SR. 2006. Modulation of Gq-protein-coupled inositol trisphosphate and $\mathrm{Ca}^{2+}$ signaling by the membrane potential. J Neurosci 26: $9983-9995$.

Bito H, Deisseroth K, Tsien RW. 1996. CREB phosphorylation and dephosphorylation: $\mathrm{A} \mathrm{Ca}^{2+}$ - and stimulus duration-dependent switch for hippocampal gene expression. Cell 87: 1203-1214.

Bkaily G, Avedanian L, Jacques D. 2009. Nuclear membrane receptors and channels as targets for drug development in cardiovascular diseases. Can J Physiol Pharmacol 87: $108-119$.

Bolger TA, Yao TP. 2005. Intracellular trafficking of histone deacetylase 4 regulates neuronal cell death. J Neurosci 25: 9544-9553.

Bootman M, Niggli E, Berridge M, Lipp P. 1997. Imaging the hierarchical $\mathrm{Ca}^{2+}$ signalling system in HeLa cells. J Physiol 4992: 307-314.

Bootman MD, Fearnley C, Smyrnias I, Macdonald F, Roderick HL. 2009. An update on nuclear calcium signalling. J Cell Sci 122: 2337-2350.

Bossy-Wetzel E, Schwarzenbacher R, Lipton SA. 2004. Molecular pathways to neurodegeneration. Nat Med 10 (Suppl): S2-S9.

Brami-Cherrier K, Roze E, Girault JA, Betuing S, Caboche J. 2009. Role of the ERK/MSK1 signalling pathway in chromatin remodelling and brain responses to drugs of abuse. J Neurochem 108: 1323-1335.

Brunet A, Bonni A, Zigmond MJ, Lin MZ, Juo P, Hu LS, Anderson MJ, Arden KC, Blenis J, Greenberg ME. 1999. Akt promotes cell survival by phosphorylating and inhibiting a Forkhead transcription factor. Cell 96: 857-868.

Bugrim AE. 1999. Regulation of $\mathrm{Ca}^{2+}$ release by cAMPdependent protein kinase. A mechanism for agonistspecific calcium signaling? Cell Calcium 25: 219-226.

Caceres A, Bender P, Snavely L, Rebhun LI, Steward O. 1983. Distribution and subcellular localization of calmodulin in adult and developing brain tissue. Neuroscience 10: $449-461$.

Callamaras N, Marchant JS, Sun XP, Parker I. 1998. Activation and co-ordination of InsP3-mediated elementary $\mathrm{Ca}^{2+}$ events during global $\mathrm{Ca}^{2+}$ signals in Xenopus oocytes. J Physiol 5091: 81-91.

Carrasco MA, Jaimovich E, Kemmerling U, Hidalgo C. 2004. Signal transduction and gene expression regulated by calcium release from internal stores in excitable cells. Biol Res 37: 701-712.

Carrion AM, Link WA, Ledo F, Mellstrom B, Naranjo JR. 1999. DREAM is a $\mathrm{Ca}^{2+}$-regulated transcriptional repressor. Nature 398: $80-84$.

Castren E, Berninger B, Leingartner A, Lindholm D. 1998. Regulation of brain-derived neurotrophic factor mRNA levels in hippocampus by neuronal activity. Prog Brain Res 117: 57-64.

Catterall WA, Perez-Reyes E, Snutch TP, Striessnig J. 2005. International Union of Pharmacology. XLVIII. Nomenclature and structure-function relationships of voltagegated calcium channels. Pharmacol Rev 57: 411-425.

Chahrour M, Jung SY, Shaw C, Zhou X, Wong ST, Qin J, Zoghbi HY. 2008. MeCP2, a key contributor to neurological disease, activates and represses transcription. Science 320: $1224-1229$.

Chandler LJ, Sutton G, Dorairaj NR, Norwood D. 2001. $\mathrm{N}$-methyl D-aspartate receptor-mediated bidirectional control of extracellular signal-regulated kinase activity in cortical neuronal cultures. J Biol Chem 276: $2627-$ 2636.

Chandramohan Y, Droste SK, Arthur JS, Reul JM. 2008. The forced swimming-induced behavioural immobility response involves histone $\mathrm{H} 3$ phospho-acetylation and c-Fos induction in dentate gyrus granule neurons via activation of the N-methyl-D-aspartate/extracellular signal-regulated kinase/mitogen- and stress-activated kinase signalling pathway. Eur J Neurosci 27: 2701-2713.

Chawla S. 2002. Regulation of gene expression by $\mathrm{Ca}^{2+}$ signals in neuronal cells. Eur J Pharmacol 447: 131-140.

Chawla S, Bading H. 2001. CREB/CBP and SRE-interacting transcriptional regulators are fast on-off switches: Duration of calcium transients specifies the magnitude of transcriptional responses. J Neurochem 79: 849-858.

Chawla S, Hardingham GE, Quinn DR, Bading H. 1998. CBP: A signal-regulated transcriptional coactivator controlled by nuclear calcium and CaM kinase IV. Science 281: 1505-1509.

Chawla S, Vanhoutte P, Arnold FJ, Huang CL, Bading H. 2003. Neuronal activity-dependent nucleocytoplasmic shuttling of HDAC4 and HDAC5. J Neurochem 85: 151-159.

Chen WG, Chang Q, Lin Y, Meissner A, West AE, Griffith EC, Jaenisch R, Greenberg ME. 2003. Derepression of BDNF transcription involves calcium-dependent phosphorylation of MeCP2. Science 302: 885-889.

Choi YM, Kim SH, Chung S, Uhm DY, Park MK. 2006. Regional interaction of endoplasmic reticulum $\mathrm{Ca}^{2+}$ signals between soma and dendrites through rapid luminal $\mathrm{Ca}^{2+}$ diffusion. J Neurosci 26: 12127-12136.

Chow FA, Anderson KA, Noeldner PK, Means AR. 2005. The autonomous activity of calcium/calmodulindependent protein kinase IV is required for its role in transcription. J Biol Chem 280: 20530-20538.

Chuderland D, Konson A, Seger R. 2008. Identification and characterization of a general nuclear translocation signal in signaling proteins. Mol Cell 31: 850-861.

Chwang WB, O’Riordan KJ, Levenson JM, Sweatt JD. 2006. ERK/MAPK regulates hippocampal histone 
A.M. Hagenston and $\mathrm{H}$. Bading

phosphorylation following contextual fear conditioning. Learn Mem 13: 322-328.

Chwang WB, Arthur JS, Schumacher A, Sweatt JD. 2007. The nuclear kinase mitogen- and stress-activated protein kinase 1 regulates hippocampal chromatin remodeling in memory formation. J Neurosci 27: 12732-12742.

Cohen S, Greenberg ME. 2008. Communication between the synapse and the nucleus in neuronal development, plasticity, and disease. Annu Rev Cell Dev Biol 24: 183 209.

Cole AJ, Saffen DW, Baraban JM, Worley PF. 1989. Rapid increase of an immediate early gene messenger RNA in hippocampal neurons by synaptic NMDA receptor activation. Nature 340: 474-476.

Cruzalegui FH, Bading H. 2000. Calcium-regulated protein kinase cascades and their transcription factor targets. Cell Mol Life Sci 57: 402-410.

Dai R, Ali MK, Lezcano N, Bergson C. 2008. A crucial role for cAMP and protein kinase a in $\mathrm{d} 1$ dopamine receptor regulated intracellular calcium transients. Neurosignals 16: $112-123$.

Dai S, Hall DD, Hell JW. 2009. Supramolecular assemblies and localized regulation of voltage-gated ion channels. Physiol Rev 89: 411-452.

Danker T, Shahin V, Schlune A, Schafer C, Oberleithner H. 2001. Electrophoretic plugging of nuclear pores by using the nuclear hourglass technique. J Membr Biol 184: 91-99.

Deisseroth K, Bito H, Tsien RW. 1996. Signaling from synapse to nucleus: Postsynaptic CREB phosphorylation during multiple forms of hippocampal synaptic plasticity. Neuron 16: 89-101.

Deisseroth K, Heist EK, Tsien RW. 1998. Translocation of calmodulin to the nucleus supports CREB phosphorylation in hippocampal neurons. Nature 392: 198-202.

Dick O, Bading H. 2010. Synaptic activity and nuclear calcium signaling protect hippocampal neurons from death signal-associated nuclear translocation of FoxO3a induced by extrasynaptic N-methyl-D-aspartate receptors. J Biol Chem 285: 19354-19361.

Dieterich DC, Karpova A, Mikhaylova M, Zdobnova I, Konig I, Landwehr M, Kreutz M, Smalla KH, Richter K, Landgraf P, et al. 2008. Caldendrin-Jacob: A protein liaison that couples NMDA receptor signalling to the nucleus. PLoS Biol 6: e34.

Dolmetsch RE, Pajvani U, Fife K, Spotts JM, Greenberg ME. 2001. Signaling to the nucleus by an L-type calcium channel-calmodulin complex through the MAP kinase pathway. Science 294: 333-339.

Duclot F, Meffre J, Jacquet C, Gongora C, Maurice T. 2010. Mice knock out for the histone acetyltransferase p300/ CREB binding protein-associated factor develop a resistance to amyloid toxicity. Neuroscience 167: 850-863.

Dudek SM, Fields RD. 2001. Mitogen-activated protein kinase/extracellular signal-regulated kinase activation in somatodendritic compartments: Roles of action potentials, frequency, and mode of calcium entry. J Neurosci 21: RC122.

Dudek SM, Fields RD. 2002. Somatic action potentials are sufficient for late-phase LTP-related cell signaling. Proc Natl Acad Sci 99: 3962-3967.
Echevarria W, Leite MF, Guerra MT, Zipfel WR, Nathanson MH. 2003. Regulation of calcium signals in the nucleus by a nucleoplasmic reticulum. Nat Cell Biol 5: 440-446.

Eder A, Bading H. 2007. Calcium signals can freely cross the nuclear envelope in hippocampal neurons: Somatic calcium increases generate nuclear calcium transients. BMC Neurosci 8: 57.

Emptage N, Bliss TV, Fine A. 1999. Single synaptic events evoke NMDA receptor-mediated release of calcium from internal stores in hippocampal dendritic spines. Neuron 22: 115-124.

Erickson ES, Mooren OL, Moore D, Krogmeier JR, Dunn RC. 2006. The role of nuclear envelope calcium in modifying nuclear pore complex structure. Can J Physiol Pharmacol 84: 309-318.

Etkin A, Alarcon JM, Weisberg SP, Touzani K, Huang YY, Nordheim A, Kandel ER. 2006. A role in learning for SRF: Deletion in the adult forebrain disrupts LTD and the formation of an immediate memory of a novel context. Neuron 50: 127-143.

Fagerlund R, Melen K, Cao X, Julkunen I. 2008. NF-кB p52, RelB and c-Rel are transported into the nucleus via a subset of importin $\alpha$ molecules. Cell Signal 20: 1442-1451.

Favaron M, Manev RM, Rimland JM, Candeo P, Beccaro M, Manev H. 1993. NMDA-stimulated expression of BDNF mRNA in cultured cerebellar granule neurones. Neuroreport 4: 1171-1174.

Feng J, Zhou Y, Campbell SL, Le T, Li E, Sweatt JD, Silva AJ, Fan G. 2010. Dnmtl and Dnmt3a maintain DNA methylation and regulate synaptic function in adult forebrain neurons. Nat Neurosci 13: 423-430.

Fischer A, Sananbenesi F, Wang X, Dobbin M, Tsai LH. 2007. Recovery of learning and memory is associated with chromatin remodelling. Nature 447: 178-182.

Fitzpatrick JS, Hagenston AM, Hertle DN, Gipson KE, Bertetto-D'Angelo L, Yeckel MF. 2009. Inositol-1,4,5trisphosphate receptor-mediated $\mathrm{Ca}^{2+}$ waves in pyramidal neuron dendrites propagate through hot spots and cold spots. J Physiol 587: 1439-1459.

Flavell SW, Cowan CW, Kim TK, Greer PL, Lin Y, Paradis S, Griffith EC, Hu LS, Chen C, Greenberg ME. 2006. Activity-dependent regulation of MEF2 transcription factors suppresses excitatory synapse number. Science 311: 1008-1012.

Fontan-Lozano A, Romero-Granados R, del-Pozo-Martin Y, Suarez-Pereira I, Delgado-Garcia JM, Penninger JM, Carrion AM. 2009. Lack of DREAM protein enhances learning and memory and slows brain aging. Curr Biol 19: $54-60$.

Foskett JK, White C, Cheung KH, Mak DO. 2007. Inositol trisphosphate receptor $\mathrm{Ca}^{2+}$ release channels. Physiol Rev 87: 593-658.

Francis JS, Dragunow M, During MJ. 2004. Over expression of ATF-3 protects rat hippocampal neurons from in vivo injection of kainic acid. Brain Res Mol Brain Res 124: 199-203.

Friel D. 2004. Interplay between $\mathrm{ER} \mathrm{Ca}^{2+}$ uptake and release fluxes in neurons and its impact on $\left[\mathrm{Ca}^{2+}\right]$ dynamics. Biol Res 37: 665-674. 


\author{
Neuronal $\mathrm{Ca}^{2+}$ Signaling to the Nucleus
}

Gall C, Lauterborn J. 1992. The dentate gyrus: A model system for studies of neurotrophin regulation. Epilepsy Res Suppl 7: 171-185.

Gao C, Gill MB, Tronson NC, Guedea AL, Guzman YF, Huh KH, Corcoran KA, Swanson GT, Radulovic J. 2010 Hippocampal NMDA receptor subunits differentially regulate fear memory formation and neuronal signal propagation. Hippocampus 20: 1072-1082.

Gerasimenko JV, Maruyama Y, Yano K, Dolman NJ, Tepikin AV, Petersen OH, Gerasimenko OV. 2003. NAADP mobilizes $\mathrm{Ca}^{2+}$ from a thapsigargin-sensitive store in the nuclear envelope by activating ryanodine receptors. J Cell Biol 163: 271-282.

Gilley J, Coffer PJ, Ham J. 2003. FOXO transcription factors directly activate bim gene expression and promote apoptosis in sympathetic neurons. J Cell Biol 162: 613-622.

Graef IA, Mermelstein PG, Stankunas K, Neilson JR, Deisseroth K, Tsien RW, Crabtree GR. 1999. L-type calcium channels and GSK-3 regulate the activity of NF-ATc4 in hippocampal neurons. Nature 401: 703-708.

Graff J, Mansuy IM. 2009. Epigenetic dysregulation in cognitive disorders. Eur J Neurosci 30: 1-8.

Gray PC, Johnson BD, Westenbroek RE, Hays LG, Yates JR III, Scheuer T, Catterall WA, Murphy BJ. 1998. Primary structure and function of an A kinase anchoring protein associated with calcium channels. Neuron 20: $1017-$ 1026.

Greber UF, Gerace L. 1995. Depletion of calcium from the lumen of endoplasmic reticulum reversibly inhibits passive diffusion and signal-mediated transport into the nucleus. J Cell Biol 128: 5-14.

Greenberg ME, Xu B, Lu B, Hempstead BL. 2009. New insights in the biology of BDNF synthesis and release: Implications in CNS function. J Neurosci 29: $12764-$ 12767.

Greer PL, Greenberg ME. 2008. From synapse to nucleus: Calcium-dependent gene transcription in the control of synapse development and function. Neuron 59: 846-860.

Gulledge AT, Stuart GJ. 2005. Cholinergic inhibition of neocortical pyramidal neurons. J Neurosci 25: 10308-10320.

Hagenston AM, Fitzpatrick JS, Yeckel MF. 2008. MGluRmediated calcium waves that invade the soma regulate firing in layer $\mathrm{V}$ medial prefrontal cortical pyramidal neurons. Cereb Cortex 18: 407-423.

Hansen HH, Briem T, Dzietko M, Sifringer M, Voss A, Rzeski W, Zdzisinska B, Thor F, Heumann R, Stepulak A, et al. 2004. Mechanisms leading to disseminated apoptosis following NMDA receptor blockade in the developing rat brain. Neurobiol Dis 16: 440-453.

Hardingham GE. 2009. Coupling of the NMDA receptor to neuroprotective and neurodestructive events. Biochem Soc Trans 37: 1147-1160.

Hardingham GE, Bading H. 1998. Nuclear calcium: a key regulator of gene expression. Biometals 11: 345-358.

Hardingham GE, Bading H. 2002. Coupling of extrasynaptic NMDA receptors to a CREB shut-off pathway is developmentally regulated. Biochim Biophys Acta 1600: 148-153.

Hardingham GE, Bading H. 2003. The Yin and Yang of NMDA receptor signalling. Trends Neurosci 26: 81-89.

Hardingham GE, Bading H. 2010. Synaptic versus extrasynaptic NMDA receptor signalling: implications for neurodegenerative disorders. Nat Rev Neurosci 11: 682 696.

Hardingham GE, Chawla S, Johnson CM, Bading H. 1997. Distinct functions of nuclear and cytoplasmic calcium in the control of gene expression. Nature 385: 260-265.

Hardingham GE, Chawla S, Cruzalegui FH, Bading H. 1999. Control of recruitment and transcription-activating function of CBP determines gene regulation by NMDA receptors and L-type calcium channels. Neuron 22: $789-798$.

Hardingham GE, Arnold FJ, Bading H. 2001a. A calcium microdomain near NMDA receptors: on switch for ERK-dependent synapse-to-nucleus communication. Nat Neurosci 4: 565-566.

Hardingham GE, Arnold FJ, Bading H. 2001b. Nuclear calcium signaling controls CREB-mediated gene expression triggered by synaptic activity. Nat Neurosci 4: 261-267.

Hardingham GE, Fukunaga Y, Bading H. 2002. Extrasynaptic NMDARs oppose synaptic NMDARs by triggering CREB shut-off and cell death pathways. Nat Neurosci 5: 405-414.

Harvey CD, Yasuda R, Zhong H, Svoboda K. 2008. The spread of Ras activity triggered by activation of a single dendritic spine. Science 321: 136-140.

Hell JW, Westenbroek RE, Warner C, Ahlijanian MK, Prystay W, Gilbert MM, Snutch TP, Catterall WA. 1993. Identification and differential subcellular localization of the neuronal class $\mathrm{C}$ and class D L-type calcium channel $\alpha 1$ subunits. J Cell Biol 123: 949-962.

Hong M, Ross WN. 2007. Priming of intracellular calcium stores in rat CA1 pyramidal neurons. J Physiol 584: 75-87.

Hong EJ, West AE, Greenberg ME. 2005. Transcriptional control of cognitive development. Curr Opin Neurobiol 15: $21-28$.

Hoskins B, Burton CK, Liu DD, Porter AB, Ho IK. 1986. Regional and subcellular calmodulin content of rat brain. J Neurochem 46: 303-304.

Hu SC, Chrivia J, Ghosh A. 1999. Regulation of CBPmediated transcription by neuronal calcium signaling. Neuron 22: 799-808.

Hu M, Liu QS, Chang KT, Berg DK. 2002. Nicotinic regulation of CREB activation in hippocampal neurons by glutamatergic and nonglutamatergic pathways. Mol Cell Neurosci 21: 616-625.

Humbert JP, Matter N, Artault JC, Koppler P, Malviya AN. 1996. Inositol 1,4,5-trisphosphate receptor is located to the inner nuclear membrane vindicating regulation of nuclear calcium signaling by inositol 1,4,5-trisphosphate. Discrete distribution of inositol phosphate receptors to inner and outer nuclear membranes. J Biol Chem 271: $478-485$.

Husi H, Ward MA, Choudhary JS, Blackstock WP, Grant SG. 2000. Proteomic analysis of NMDA receptor-adhesion protein signaling complexes. Nat Neurosci 3: 661-669.

Impey S, Fong AL, Wang Y, Cardinaux JR, Fass DM, Obrietan K, Wayman GA, Storm DR, Soderling TR, Goodman RH. 2002. Phosphorylation of CBP mediates transcriptional activation by neural activity and CaM kinase IV. Neuron 34: 235-244. 
A.M. Hagenston and H. Bading

Ivanov A, Pellegrino C, Rama S, Dumalska I, Salyha Y, Ben-Ari Y, Medina I. 2006. Opposing role of synaptic and extrasynaptic NMDA receptors in regulation of the extracellular signal-regulated kinases (ERK) activity in cultured rat hippocampal neurons. J Physiol 572: 789798.

Jaffe DB, Brown TH. 1994. Metabotropic glutamate receptor activation induces calcium waves within hippocampal dendrites. J Neurophysiol 72: 471-474.

Jeffrey RA, Ch'ng TH, O’Dell TJ, Martin KC. 2009. Activitydependent anchoring of importin $\alpha$ at the synapse involves regulated binding to the cytoplasmic tail of the NR1-1a subunit of the NMDA receptor. J Neurosci 29: 15613-15620.

Jensen KF, Ohmstede CA, Fisher RS, Sahyoun N. 1991. Nuclear and axonal localization of $\mathrm{Ca}^{2+} /$ calmodulindependent protein kinase type $\mathrm{Gr}$ in rat cerebellar cortex. Proc Natl Acad Sci 88: 2850-2853.

Jiang X, Tian F, Mearow K, Okagaki P, Lipsky RH, Marini AM. 2005. The excitoprotective effect of Nmethyl-D-aspartate receptors is mediated by a brainderived neurotrophic factor autocrine loop in cultured hippocampal neurons. J Neurochem 94: 713-722.

Jiang H, Poirier MA, Liang Y, Pei Z, Weiskittel CE, Smith WW, DeFranco DB, Ross CA. 2006. Depletion of CBP is directly linked with cellular toxicity caused by mutant huntingtin. Neurobiol Dis 23: 543-551.

Johenning FW, Holthoff K. 2007. Nuclear calcium signals during L-LTP induction do not predict the degree of synaptic potentiation. Cell Calcium 41: 271-283.

Jonas P, Burnashev N. 1995. Molecular mechanisms controlling calcium entry through AMPA-type glutamate receptor channels. Neuron 15: 987-990.

Jones PL, Veenstra GJ, Wade PA, Vermaak D, Kass SU, Landsberger N, Strouboulis J, Wolffe AP. 1998. Methylated DNA and MeCP2 recruit histone deacetylase to repress transcription. Nat Genet 19: 187-191.

Jong YJ, Kumar V, Kingston AE, Romano C, O’Malley KL. 2005. Functional metabotropic glutamate receptors on nuclei from brain and primary cultured striatal neurons. Role of transporters in delivering ligand. J Biol Chem 280: 30469-30480.

Jong YJ, Schwetye KE, O’Malley KL. 2007. Nuclear localization of functional metabotropic glutamate receptor mGlu1 in HEK293 cells and cortical neurons: role in nuclear calcium mobilization and development. J Neurochem 101: 458-469.

Jordan BA, Kreutz MR. 2009. Nucleocytoplasmic protein shuttling: the direct route in synapse-to-nucleus signaling. Trends Neurosci 32: 392-401.

Jordan BA, Fernholz BD, Khatri L, Ziff EB. 2007. Activitydependent AIDA-1 nuclear signaling regulates nucleolar numbers and protein synthesis in neurons. Nat Neurosci 10: $427-435$.

Jorgensen HF, Bird A. 2002. MeCP2 and other methylCpG binding proteins. Ment Retard Dev Disabil Res Rev 8: 87-93.

Kalia LV, Kalia SK, Salter MW. 2008. NMDA receptors in clinical neurology: Excitatory times ahead. Lancet Neurol 7: 742-755.
Kapur A, Yeckel M, Johnston D. 2001. Hippocampal mossy fiber activity evokes $\mathrm{Ca} 2+$ release in CA3 pyramidal neurons via a metabotropic glutamate receptor pathway. Neuroscience 107: 59-69.

Kasahara J, Fukunaga K, Miyamoto E. 1999. Differential effects of a calcineurin inhibitor on glutamate-induced phosphorylation of $\mathrm{Ca}^{2+} /$ calmodulin-dependent protein kinases in cultured rat hippocampal neurons. J Biol Chem 274: 9061-9067.

Korkotian E, Segal M. 1999. Release of calcium from stores alters the morphology of dendritic spines in cultured hippocampal neurons. Proc Natl Acad Sci 96: 12068-12072.

Korzus E, Rosenfeld MG, Mayford M. 2004. CBP histone acetyltransferase activity is a critical component of memory consolidation. Neuron 42: 961-972.

Koshibu K, Graff J, Beullens M, Heitz FD, Berchtold D, Russig H, Farinelli M, Bollen M, Mansuy IM. 2009. Protein phosphatase 1 regulates the histone code for long-term memory. J Neurosci 29: 13079-13089.

Kotera I, Sekimoto T, Miyamoto Y, Saiwaki T, Nagoshi E, Sakagami H, Kondo H, Yoneda Y. 2005. Importin $\alpha$ transports CaMKIV to the nucleus without utilizing importin ß. EMBO J 24: 942-951.

Kramer JM, van Bokhoven H. 2009. Genetic and epigenetic defects in mental retardation. Int J Biochem Cell Biol 41: 96-107.

Krapivinsky G, Krapivinsky L, Manasian Y, Ivanov A, Tyzio R, Pellegrino C, Ben-Ari Y, Clapham DE, Medina I. 2003. The NMDA receptor is coupled to the ERK pathway by a direct interaction between NR2B and RasGRF1. Neuron 40: $775-784$.

Kumar V, Jong YJ, O’Malley KL. 2008. Activated nuclear metabotropic glutamate receptor mGlu5 couples to nuclear $\mathrm{Gq} / 11$ proteins to generate inositol $1,4,5$ trisphosphate-mediated nuclear $\mathrm{Ca}^{2+}$ release. J Biol Chem 283: 14072-14083.

Lai KO, Zhao Y, Ch'ng TH, Martin KC. 2008. Importinmediated retrograde transport of CREB2 from distal processes to the nucleus in neurons. Proc Natl Acad Sci 105: 17175-17180.

Lalonde J, Lachance PE, Chaudhuri A. 2004. Monocular enucleation induces nuclear localization of calcium/ calmodulin-dependent protein kinase IV in cortical interneurons of adult monkey area V1. J Neurosci 24: $554-564$.

Lange A, Mills RE, Lange CJ, Stewart M, Devine SE, Corbett AH. 2007. Classical nuclear localization signals: definition, function, and interaction with importin $\alpha$.J Biol Chem 282: 5101-5105.

Larkum ME, Watanabe S, Nakamura T, Lasser-Ross N, Ross WN. 2003. Synaptically activated $\mathrm{Ca}^{2+}$ waves in layer $2 / 3$ and layer 5 rat neocortical pyramidal neurons. J Physiol 549: $471-488$.

Lau D, Bading H. 2009. Synaptic activity-mediated suppression of p53 and induction of nuclear calcium-regulated neuroprotective genes promote survival through inhibition of mitochondrial permeability transition. J Neurosci 29: $4420-4429$.

Ledo F, Carrion AM, Link WA, Mellstrom B, Naranjo JR. 2000. DREAM- $\alpha$ CREM interaction via leucine-charged domains derepresses downstream regulatory elementdependent transcription. Mol Cell Biol 20: 9120-9126. 
Ledo F, Kremer L, Mellstrom B, Naranjo JR. 2002. $\mathrm{Ca}^{2+}$. dependent block of CREB-CBP transcription by repressor DREAM. EMBO J 21: 4583-4592.

Lee MA, Dunn RC, Clapham DE, Stehno-Bittel L. 1998. Calcium regulation of nuclear pore permeability. Cell Calcium 23: 91-101.

Legube G, Trouche D. 2003. Regulating histone acetyltransferases and deacetylases. EMBO Rep 4: 944-947.

Leitch B, Szostek A, Lin R, Shevtsova O. 2009. Subcellular distribution of L-type calcium channel subtypes in rat hippocampal neurons. Neuroscience 164: 641-657.

Lemrow SM, Anderson KA, Joseph JD, Ribar TJ, Noeldner PK, Means AR. 2004. Catalytic activity is required for calcium/calmodulin-dependent protein kinase IV to enter the nucleus. J Biol Chem 279: 11664-11671.

Leveille F, El Gaamouch F, Gouix E, Lecocq M, Lobner D, Nicole O, Buisson A. 2008. Neuronal viability is controlled by a functional relation between synaptic and extrasynaptic NMDA receptors. FASEB J 22: 4258-4271.

Leveille F, Papadia S, Fricker M, Bell KF, Soriano FX, Martel MA, Puddifoot C, Habel M, Wyllie DJ, Ikonomidou C, et al. 2010. Suppression of the intrinsic apoptosis pathway by synaptic activity. J Neurosci 30: 2623-2635.

Levenson JM, Sweatt JD. 2006. Epigenetic mechanisms: a common theme in vertebrate and invertebrate memory formation. Cell Mol Life Sci 63: 1009-1016.

Levenson JM, Roth TL, Lubin FD, Miller CA, Huang IC, Desai P, Malone LM, Sweatt JD. 2006. Evidence that DNA (cytosine-5) methyltransferase regulates synaptic plasticity in the hippocampus. J Biol Chem 281: 15763-15773.

Lezcano N, Bergson C. 2002. D1/D5 dopamine receptors stimulate intracellular calcium release in primary cultures of neocortical and hippocampal neurons. J Neurophysiol 87: 2167-2175.

Li YX, Keizer J, Stojilkovic SS, Rinzel J. 1995. $\mathrm{Ca}^{2+}$ excitability of the ER membrane: an explanation for IP3-induced $\mathrm{Ca}^{2+}$ oscillations. Am J Physiol 269: C1079-1092.

Li QJ, Yang SH, Maeda Y, Sladek FM, Sharrocks AD, Martins-Green M. 2003. MAP kinase phosphorylationdependent activation of Elk-1 leads to activation of the co-activator 300. EMBO J 22: 281-291.

Lilliehook C, Bozdagi O, Yao J, Gomez-Ramirez M, Zaidi NF, Wasco W, Gandy S, Santucci AC, Haroutunian V, Huntley GW, et al. 2003. Altered $A \beta$ formation and longterm potentiation in a calsenilin knock-out. J Neurosci 23: 9097-9106.

Limback-Stokin K, Korzus E, Nagaoka-Yasuda R, Mayford M. 2004. Nuclear calcium/calmodulin regulates memory consolidation. J Neurosci 24: 10858-10867.

Liu Z, Ren J, Murphy TH. 2003. Decoding of synaptic voltage waveforms by specific classes of recombinant highthreshold $\mathrm{Ca}^{2+}$ channels. J Physiol 553: 473-488.

Liu Y, Wong TP, Aarts M, Rooyakkers A, Liu L, Lai TW, Wu DC, Lu J, Tymianski M, Craig AM, et al. 2007. NMDA receptor subunits have differential roles in mediating excitotoxic neuronal death both in vitro and in vivo. J Neurosci 27: 2846-2857.

Liu QH, Zheng YM, Korde AS, Yadav VR, Rathore R, Wess J Wang YX. 2009. Membrane depolarization causes a direct activation of $\mathrm{G}$ protein-coupled receptors leading to local
$\mathrm{Ca}^{2+}$ release in smooth muscle. Proc Natl Acad Sci U S A 106: $11418-11423$.

Lubin FD, Roth TL, Sweatt JD. 2008. Epigenetic regulation of BDNF gene transcription in the consolidation of fear memory. J Neurosci 28: 10576-10586.

Ma DK, Guo JU, Ming GL, Song H. 2009. DNA excision repair proteins and Gadd45 as molecular players for active DNA demethylation. Cell Cycle 8: 1526-1531.

Mao LM, Zhang GC, Liu XY, Fibuch EE, Wang JQ. 2008. Group I metabotropic glutamate receptor-mediated gene expression in striatal neurons. Neurochem Res 33: 1920-1924.

Marchenko SM, Thomas RC. 2006. Nuclear $\mathrm{Ca}^{2+}$ signalling in cerebellar Purkinje neurons. Cerebellum 5: 36-42.

Marchenko SM, Yarotskyy VV, Kovalenko TN, Kostyuk PG, Thomas RC. 2005. Spontaneously active and InsP3activated ion channels in cell nuclei from rat cerebellar Purkinje and granule neurones. J Physiol 565: 897-910.

Martin C, Ashley RH. 1993. Reconstitution of a voltageactivated calcium conducting cation channel from brain microsomes. Cell Calcium 14: 427-438.

Martinowich K, Hattori D, Wu H, Fouse S, He F, Hu Y, Fan G, Sun YE. 2003. DNA methylation-related chromatin remodeling in activity-dependent BDNF gene regulation. Science 302: 890-893.

Matthews RP, Guthrie CR, Wailes LM, Zhao X, Means AR, McKnight GS. 1994. Calcium/calmodulin-dependent protein kinase types II and IV differentially regulate CREB-dependent gene expression. Mol Cell Biol 14: 6107-6116.

Matzke AJM, Matzke MA. 1991. The electrical properties of the nuclear envelope, and their possible role in the regulation of eukaryotic gene expression. Bioelectrochem Bioenerg 25: 357-370.

Matzke AJ, Weiger TM, Matzke M. 2010. Ion channels at the nucleus: Electrophysiology meets the genome. Mol Plant 3: 642-652.

Mauceri D, Freitag HE, Oliveira AM, Bengtson CP, Bading H. 2011. Nuclear calcium-VEGFD signaling controls maintenance of dendrite arborization necessary for memory formation. Neuron 71: 117-130.

Mazzanti M, Bustamante JO, Oberleithner H. 2001. Electrical dimension of the nuclear envelope. Physiol Rev 81: 1-19.

McKinsey TA, Zhang CL, Olson EN. 2000. Activation of the myocyte enhancer factor-2 transcription factor by calcium/calmodulin-dependent protein kinase-stimulated binding of 14-3-3 to histone deacetylase 5. Proc Natl Acad Sci 97: 14400-14405.

Means AR. 2000. Regulatory cascades involving calmodulin-dependent protein kinases. Mol Endocrinol 14: 4-13.

Meffert MK, Chang JM, Wiltgen BJ, Fanselow MS, Baltimore D. 2003. NF-кB functions in synaptic signaling and behavior. Nat Neurosci 6: 1072-1078.

Mellstrom B, Torres B, Link WA, Naranjo JR. 2004. The BDNF gene: Exemplifying complexity in $\mathrm{Ca}^{2+}$ dependent gene expression. Crit Rev Neurobiol 16: $43-$ 49.

Mermelstein PG, Bito H, Deisseroth K, Tsien RW. 2000. Critical dependence of cAMP response element-binding protein phosphorylation on L-type calcium channels 
A.M. Hagenston and H. Bading

supports a selective response to EPSPs in preference to action potentials. J Neurosci 20: $266-273$.

Mermelstein PG, Deisseroth K, Dasgupta N, Isaksen AL, Tsien RW. 2001. Calmodulin priming: nuclear translocation of a calmodulin complex and the memory of prior neuronal activity. Proc Natl Acad Sci 98: 15342-15347.

Miller CA, Sweatt JD. 2007. Covalent modification of DNA regulates memory formation. Neuron 53: 857-869.

Miller CA, Campbell SL, Sweatt JD. 2008. DNA methylation and histone acetylation work in concert to regulate memory formation and synaptic plasticity. Neurobiol Learn Mem 89: 599-603.

Miller CA, Gavin CF, White JA, Parrish RR, Honasoge A, Yancey CR, Rivera IM, Rubio MD, Rumbaugh G, Sweatt JD. 2010. Cortical DNA methylation maintains remote memory. Nat Neurosci 13: 664-666.

Milnerwood AJ, Gladding CM, Pouladi MA, Kaufman AM, Hines RM, Boyd JD, Ko RW, Vasuta OC, Graham RK Hayden MR, et al. 2010. Early increase in extrasynaptic NMDA receptor signaling and expression contributes to phenotype onset in Huntington's disease mice. Neuron 65: $178-190$.

Missiaen L, De Smedt H, Droogmans G, Casteels R. 1992 $\mathrm{Ca}^{2+}$ release induced by inositol 1,4,5-trisphosphate is a steady-state phenomenon controlled by luminal $\mathrm{Ca}^{2+}$ in permeabilized cells. Nature 357: 599-602.

Morikawa H, Imani F, Khodakhah K, Williams JT. 2000. Inositol 1,4,5-triphosphate-evoked responses in midbrain dopamine neurons. J Neurosci 20: RC103.

Murphy TH, Worley PF, Baraban JM. 1991. L-type voltagesensitive calcium channels mediate synaptic activation of immediate early genes. Neuron 7: 625-635.

Nakamura Y, Okuno S, Sato F, Fujisawa H. 1995. An immunohistochemical study of $\mathrm{Ca}^{2+} /$ calmodulin-dependent protein kinase IV in the rat central nervous system: Light and electron microscopic observations. Neuroscience 68: 181-194.

Nakamura T, Barbara JG, Nakamura K, Ross WN. 1999. Synergistic release of $\mathrm{Ca}^{2+}$ from IP3-sensitive stores evoked by synaptic activation of mGluRs paired with backpropagating action potentials. Neuron 24: 727-737.

Nakamura T, Lasser-Ross N, Nakamura K, Ross WN. 2002. Spatial segregation and interaction of calcium signalling mechanisms in rat hippocampal CA1 pyramidal neurons. J Physiol 543: 465-480.

Nan X, Ng HH, Johnson CA, Laherty CD, Turner BM, Eisenman RN, Bird A. 1998. Transcriptional repression by the methyl-CpG-binding protein $\mathrm{MeCP} 2$ involves a histone deacetylase complex. Nature 393: 386-389.

Nguyen PV, Abel T, Kandel ER. 1994. Requirement of a critical period of transcription for induction of a late phase of LTP. Science 265: 1104-1107.

Noguchi J, Matsuzaki M, Ellis-Davies GC, Kasai H. 2005. Spine-neck geometry determines NMDA receptordependent $\mathrm{Ca}^{2+}$ signaling in dendrites. Neuron 46: 609-622.

Obermair GJ, Szabo Z, Bourinet E, Flucher BE. 2004. Differential targeting of the L-type $\mathrm{Ca}^{2+}$ channel $\alpha 1 \mathrm{C}$ (CaV1.2) to synaptic and extrasynaptic compartments in hippocampal neurons. Eur J Neurosci 19: 2109-2122.
O’Brien EM, Gomes DA, Sehgal S, Nathanson MH. 2007. Hormonal regulation of nuclear permeability. $J$ Biol Chem 282: 4210-4217.

Okabe S. 2007. Molecular anatomy of the postsynaptic density. Mol Cell Neurosci 34: 503-518.

Oliveira AM, Abel T, Brindle PK, Wood MA. 2006. Differential role for CBP and p300 CREB-binding domain in motor skill learning. Behav Neurosci 120: 724-729.

Oliveira AM, Wood MA, McDonough CB, Abel T. 2007. Transgenic mice expressing an inhibitory truncated form of p300 exhibit long-term memory deficits. Learn Mem 14: 564-572.

Oliveria SF, Dell'Acqua ML, Sather WA. 2007. AKAP79/150 anchoring of calcineurin controls neuronal L-type $\mathrm{Ca}^{2+}$ channel activity and nuclear signaling. Neuron 55: 261-275.

O’Malley KL, Jong YJ, Gonchar Y, Burkhalter A, Romano C. 2003. Activation of metabotropic glutamate receptor mGlu5 on nuclear membranes mediates intranuclear $\mathrm{Ca}^{2+}$ changes in heterologous cell types and neurons. J Biol Chem 278: 28210-28219.

Otis KO, Thompson KR, Martin KC. 2006. Importinmediated nuclear transport in neurons. Curr Opin Neurobiol 16: 329-335.

Papadia S, Stevenson P, Hardingham NR, Bading H, Hardingham GE. 2005. Nuclear $\mathrm{Ca}^{2+}$ and the cAMP response element-binding protein family mediate a late phase of activity-dependent neuroprotection. J Neurosci 25: 4279-4287.

Park IK, Soderling TR. 1995. Activation of $\mathrm{Ca}^{2+} /$ calmodulin-dependent protein kinase (CaM-kinase) IV by CaM-kinase kinase in Jurkat T lymphocytes. $J$ Biol Chem 270: 30464-30469.

Park MK, Petersen OH, Tepikin AV. 2000. The endoplasmic reticulum as one continuous $\mathrm{Ca}^{2+}$ pool: visualization of rapid $\mathrm{Ca}^{2+}$ movements and equilibration. EMBO J 19: 5729-5739.

Park MK, Choi YM, Kang YK, Petersen OH. 2008. The endoplasmic reticulum as an integrator of multiple dendritic events. Neuroscientist 14: 68-77.

Parker I, Ivorra I. 1990. Localized all-or-none calcium liberation by inositol trisphosphate. Science 250: 977-979.

Patterson RL, Boehning D, Snyder SH. 2004. Inositol 1,4,5-trisphosphate receptors as signal integrators. Annu Rev Biochem 73: 437-465.

Perez-Terzic C, Gacy AM, Bortolon R, Dzeja PP, Puceat M, Jaconi M, Prendergast FG, Terzic A. 1999. Structural plasticity of the cardiac nuclear pore complex in response to regulators of nuclear import. Circ Res 84: 1292-1301.

Petrij F, Giles RH, Dauwerse HG, Saris JJ, Hennekam RC, Masuno M, Tommerup N, van Ommen GJ, Goodman RH, Peters DJ, et al. 1995. Rubinstein-Taybi syndrome caused by mutations in the transcriptional co-activator CBP. Nature 376: 348-351.

Pinato G, Pegoraro S, Iacono G, Ruaro ME, Torre V. 2009. Calcium control of gene regulation in rat hippocampal neuronal cultures. J Cell Physiol 220: 727-747.

Pittenger C, Huang YY, Paletzki RF, Bourtchouladze R, Scanlin H, Vronskaya S, Kandel ER. 2002. Reversible inhibition of CREB/ATF transcription factors in region 
CA1 of the dorsal hippocampus disrupts hippocampusdependent spatial memory. Neuron 34: 447-462.

Power JM, Sah P. 2002. Nuclear calcium signaling evoked by cholinergic stimulation in hippocampal CA1 pyramidal neurons. J Neurosci 22: 3454-3462.

Power JM, Sah P. 2005. Intracellular calcium store filling by an L-type calcium current in the basolateral amygdala at subthreshold membrane potentials. J Physiol 562: 439_ 453.

Power JM, Sah P. 2007. Distribution of IP3-mediated calcium responses and their role in nuclear signalling in rat basolateral amygdala neurons. J Physiol 580: 835-857.

Pozzo-Miller LD, Petrozzino JJ, Golarai G, Connor JA. 1996 $\mathrm{Ca}^{2+}$ release from intracellular stores induced by afferent stimulation of CA3 pyramidal neurons in hippocampal slices. J Neurophysiol 76: 554-562.

Quesada I, Verdugo P. 2005. InsP3 signaling induces pulsemodulated $\mathrm{Ca}^{2+}$ signals in the nucleus of airway epithelial ciliated cells. Biophys J 88: 3946-3953.

Rae MG, Martin DJ, Collingridge GL, Irving AJ. 2000. Role of $\mathrm{Ca}^{2+}$ stores in metabotropic L-glutamate receptormediated supralinear $\mathrm{Ca}^{2+}$ signaling in rat hippocampal neurons. J Neurosci 20: 8628-8636.

Rai K, Huggins IJ, James SR, Karpf AR, Jones DA, Cairns BR. 2008. DNA demethylation in zebrafish involves the coupling of a deaminase, a glycosylase, and gadd45. Cell 135: $1201-1212$.

Raymond CR. 2007. LTP forms 1, 2 and 3: Different mechanisms for the "long" in long-term potentiation. Trends Neurosci 30: 167-175.

Raymond CR, Redman SJ. 2002. Different calcium sources are narrowly tuned to the induction of different forms of LTP. J Neurophysiol 88: 249-255.

Raymond CR, Redman SJ. 2006. Spatial segregation of neuronal calcium signals encodes different forms of LTP in rat hippocampus. J Physiol 570: 97-111.

Redmond L. 2008. Translating neuronal activity into dendrite elaboration: Signaling to the nucleus. Neurosignals 16: $194-208$.

Redmond L, Kashani AH, Ghosh A. 2002. Calcium regulation of dendritic growth via CaM kinase IV and CREBmediated transcription. Neuron 34: 999-1010.

Reichenberg A, Mill J, MacCabe JH. 2009. Epigenetics, genomic mutations and cognitive function. Cogn Neuropsychiatry 14: 377-390.

Rodrigues MA, Gomes DA, Nathanson MH, Leite MF. 2009. Nuclear calcium signaling: a cell within a cell. Braz J Med Biol Res 42: 17-20.

Rose CR, Konnerth A. 2001. Stores not just for storage. intracellular calcium release and synaptic plasticity. $\mathrm{Neu}$ ron 31: 519-522.

Ryglewski S, Pflueger HJ, Duch C. 2007. Expanding the neuron's calcium signaling repertoire: Intracellular calcium release via voltage-induced PLC and IP3R activation. PLoS Biol 5: e66.

Sabatini BL, Oertner TG, Svoboda K. 2002. The life cycle of $\mathrm{Ca}^{2+}$ ions in dendritic spines. Neuron 33: 439-452.

Saha RN, Dudek SM. 2008. Action potentials: to the nucleus and beyond. Exp Biol Med (Maywood) 233: 385-393.
Sakagami H, Umemiya M, Saito S, Kondo H. 2000. Distinct immunohistochemical localization of two isoforms of $\mathrm{Ca}^{2+} /$ calmodulin-dependent protein kinase kinases in the adult rat brain. Eur J Neurosci 12: 89-99.

Sakagami H, Kamata A, Nishimura H, Kasahara J, Owada Y, Takeuchi Y, Watanabe M, Fukunaga K, Kondo H. 2005. Prominent expression and activity-dependent nuclear translocation of $\mathrm{Ca}^{2+} /$ calmodulin-dependent protein

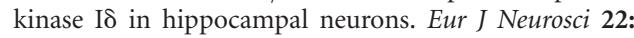
2697-2707.

Saneyoshi T, Fortin DA, Soderling TR. 2010. Regulation of spine and synapse formation by activity-dependent intracellular signaling pathways. Curr Opin Neurobiol 20: $108-115$.

Schiller J, Major G, Koester HJ, Schiller Y. 2000. NMDA spikes in basal dendrites of cortical pyramidal neurons. Nature 404: 285-289.

Schmid A, Dehlinger-Kremer M, Schulz I, Gogelein H. 1990. Voltage-dependent InsP3-insensitive calcium channels in membranes of pancreatic endoplasmic reticulum vesicles. Nature 346: 374-376.

Schneider M, Spanagel R, Zhang SJ, Bading H, Klugmann M. 2007. Adeno-associated virus (AAV)-mediated suppression of $\mathrm{Ca}^{2+} /$ calmodulin kinase IV activity in the nucleus accumbens modulates emotional behaviour in mice. BMC Neurosci 8: 105.

Scimemi A, Tian H, Diamond JS. 2009. Neuronal transporters regulate glutamate clearance, NMDA receptor activation, and synaptic plasticity in the hippocampus. J Neurosci 29: 14581-14595.

Seidenbecher CI, Langnaese K, Sanmarti-Vila L, Boeckers TM, Smalla KH, Sabel BA, Garner CC, Gundelfinger ED, Kreutz MR. 1998. Caldendrin, a novel neuronal calcium-binding protein confined to the somatodendritic compartment. J Biol Chem 273: 21324-21331.

Shahin V, Danker T, Enss K, Ossig R, Oberleithner H. 2001. Evidence for $\mathrm{Ca}^{2+}$ - and ATP-sensitive peripheral channels in nuclear pore complexes. FASEB J 15: 1895-1901.

Shalizi A, Gaudilliere B, Yuan Z, Stegmuller J, Shirogane T, Ge Q, Tan Y, Schulman B, Harper JW, Bonni A. 2006. A calcium-regulated MEF2 sumoylation switch controls postsynaptic differentiation. Science 311: 1012-1017.

Sheldon AL, Robinson MB. 2007. The role of glutamate transporters in neurodegenerative diseases and potential opportunities for intervention. Neurochem Int 51: 333355.

Shemer I, Brinne B, Tegner J, Grillner S. 2008. Electrotonic signals along intracellular membranes may interconnect dendritic spines and nucleus. PLoS Comput Biol 4: e1000036.

Sierra-Paredes G, Sierra-Marcuno G. 2007. Extrasynaptic GABA and glutamate receptors in epilepsy. CNS Neurol Disord Drug Targets 6: 288-300.

Skene PJ, Illingworth RS, Webb S, Kerr AR, James KD, Turner DJ, Andrews R, Bird AP. 2010. Neuronal MeCP2 is expressed at near histone-octamer levels and globally alters the chromatin state. Mol Cell 37: 457-468.

Solovyova N, Verkhratsky A. 2002. Monitoring of free calcium in the neuronal endoplasmic reticulum: an overview of modern approaches. J Neurosci Methods 122: $1-12$. 
A.M. Hagenston and $\mathrm{H}$. Bading

Solovyova N, Veselovsky N, Toescu EC, Verkhratsky A. 2002. $\mathrm{Ca}^{2+}$ dynamics in the lumen of the endoplasmic reticulum in sensory neurons: direct visualization of $\mathrm{Ca}^{2+}$ induced $\mathrm{Ca}^{2+}$ release triggered by physiological $\mathrm{Ca}^{2+}$ entry. EMBO J 21: 622-630.

Spruston N, Mcbain C. 2007. Structural and functional properties of hippocampal neurons. The Hippocampus book (ed. P Andersen, et al.), pp. 133-201. Oxford University Press, New York.

Stanika RI, Pivovarova NB, Brantner CA, Watts CA, Winters CA, Andrews SB. 2009. Coupling diverse routes of calcium entry to mitochondrial dysfunction and glutamate excitotoxicity. Proc Natl Acad Sci 106: 9854-9859.

Stehno-Bittel L, Perez-Terzic C, Clapham DE. 1995. Diffusion across the nuclear envelope inhibited by depletion of the nuclear $\mathrm{Ca}^{2+}$ store. Science 270: 1835-1838.

Stern MD. 1992. Buffering of calcium in the vicinity of a channel pore. Cell Calcium 13: 183-192.

Sterner DE, Berger SL. 2000. Acetylation of histones and transcription-related factors. Microbiol Mol Biol Rev 64: $435-459$.

Stoffler D, Schwarz-Herion K, Aebi U, Fahrenkrog B. 2006. Getting across the nuclear pore complex: New insights into nucleocytoplasmic transport. Can J Physiol Pharmacol 84: 499-507.

Straub SV, Wagner LE II, Bruce JI, Yule DI. 2004. Modulation of cytosolic calcium signaling by protein kinase Amediated phosphorylation of inositol 1,4,5-trisphosphate receptors. Biol Res 37: 593-602.

Stutzmann GE, LaFerla FM, Parker I. 2003. $\mathrm{Ca}^{2+}$ signaling in mouse cortical neurons studied by two-photon imaging and photoreleased inositol triphosphate. J Neurosci 23: $758-765$.

Tang TS, Tu H, Wang Z, Bezprozvanny I. 2003. Modulation of type 1 inositol $(1,4,5)$-trisphosphate receptor function by protein kinase a and protein phosphatase $1 \alpha$. J Neurosci 23: 403-415.

Tao J, Hu K, Chang Q, Wu H, Sherman NE, Martinowich K, Klose RJ, Schanen C, Jaenisch R, Wang W, et al. 2009. Phosphorylation of MeCP2 at Serine 80 regulates its chromatin association and neurological function. Proc Natl Acad Sci 106: 4882-4887.

Taylor CW. 1998. Inositol trisphosphate receptors: $\mathrm{Ca}^{2+}$ modulated intracellular $\mathrm{Ca}^{2+}$ channels. Biochim Biophys Acta 1436: 19-33.

Thompson KR, Otis KO, Chen DY, Zhao Y, O'Dell TJ, Martin KC. 2004. Synapse to nucleus signaling during longterm synaptic plasticity; a role for the classical active nuclear import pathway. Neuron 44: 997-1009.

Thrower EC, Mobasheri H, Dargan S, Marius P, Lea EJ, Dawson AP. 2000. Interaction of luminal calcium and cytosolic ATP in the control of type 1 inositol $(1,4,5)$ trisphosphate receptor channels. J Biol Chem 275: 36049-36055.

Tian F, Hu XZ, Wu X, Jiang H, Pan H, Marini AM, Lipsky RH. 2009. Dynamic chromatin remodeling events in hippocampal neurons are associated with NMDA receptormediated activation of Bdnf gene promoter 1. J Neurochem 109: 1375-1388.

Tian F, Marini AM, Lipsky RH. 2010a. NMDA receptor activation induces differential epigenetic modification of
Bdnf promoters in hippocampal neurons. Amino Acids 38: $1067-1074$.

Tian F, Marini AM, Lipsky RH. 2010b. Effects of histone deacetylase inhibitor Trichostatin A on epigenetic changes and transcriptional activation of Bdnf promoter 1 by rat hippocampal neurons. Ann NY Acad Sci 1199: 186-193.

Tolias KF, Bikoff JB, Burette A, Paradis S, Harrar D, Tavazoie S, Weinberg RJ, Greenberg ME. 2005. The Rac1-GEF Tiam1 couples the NMDA receptor to the activitydependent development of dendritic arbors and spines. Neuron 45: 525-538.

Tomida T, Hirose K, Takizawa A, Shibasaki F, Iino M. 2003. NFAT functions as a working memory of $\mathrm{Ca}^{2+}$ signals in decoding $\mathrm{Ca}^{2+}$ oscillation. EMBO J 22: 3825-3832.

Tsankova N, Renthal W, Kumar A, Nestler EJ. 2007. Epigenetic regulation in psychiatric disorders. Nat Rev Neurosci 8: $355-367$.

Vacher H, Mohapatra DP, Trimmer JS. 2008. Localization and targeting of voltage-dependent ion channels in mammalian central neurons. Physiol Rev 88: 1407-1447.

Vanderklish PW, Edelman GM. 2002. Dendritic spines elongate after stimulation of group 1 metabotropic glutamate receptors in cultured hippocampal neurons. Proc Natl Acad Sci 99: 1639-1644.

Vanhoutte P, Bading H. 2003. Opposing roles of synaptic and extrasynaptic NMDA receptors in neuronal calcium signalling and BDNF gene regulation. Curr Opin Neurobiol 13: 366-371.

Vashishta A, Habas A, Pruunsild P, Zheng JJ, Timmusk T, Hetman M. 2009. Nuclear factor of activated T-cells isoform c4 (NFATc4/NFAT3) as a mediator of antiapoptotic transcription in NMDA receptor-stimulated cortical neurons. J Neurosci 29: 15331-15340.

Verkhratsky AJ, Petersen OH. 1998. Neuronal calcium stores. Cell Calcium 24: 333-343.

Wahl AS, Buchthal B, Rode F, Bomholt SF, Freitag HE, Hardingham GE, Ronn LC, Bading H. 2009. Hypoxic/ischemic conditions induce expression of the putative pro-death gene Clcal via activation of extrasynaptic N-methyl-D-aspartate receptors. Neuroscience 158: 344-352.

Wang H, Clapham DE. 1999. Conformational changes of the in situ nuclear pore complex. Biophys J 77: 241-247.

Wang J, Campos B, Jamieson GA Jr, Kaetzel MA, Dedman JR. 1995. Functional elimination of calmodulin within the nucleus by targeted expression of an inhibitor peptide. J Biol Chem 270: 30245-30248.

Watanabe S, Hong M, Lasser-Ross N, Ross WN. 2006. Modulation of calcium wave propagation in the dendrites and to the soma of rat hippocampal pyramidal neurons. J Physiol 575: 455-468.

Wayman GA, Lee YS, Tokumitsu H, Silva AJ, Soderling TR. 2008. Calmodulin-kinases: modulators of neuronal development and plasticity. Neuron 59: 914-931.

Weick JP, Groth RD, Isaksen AL, Mermelstein PG. 2003. Interactions with PDZ proteins are required for L-type calcium channels to activate cAMP response element-binding protein-dependent gene expression. $J$ Neurosci 23: 3446-3456. 
Neuronal $\mathrm{Ca}^{2+}$ Signaling to the Nucleus

Wellmann H, Kaltschmidt B, Kaltschmidt C. 2001. Retrograde transport of transcription factor NF- $\mathrm{\kappa B}$ in living neurons. J Biol Chem 276: 11821-11829.

Westenbroek RE, Ahlijanian MK, Catterall WA. 1990. Clustering of L-type $\mathrm{Ca}^{2+}$ channels at the base of major dendrites in hippocampal pyramidal neurons. Nature 347: $281-284$.

Westphal RS, Anderson KA, Means AR, Wadzinski BE. 1998. A signaling complex of $\mathrm{Ca}^{2+}$-calmodulin-dependent protein kinase IV and protein phosphatase $2 \mathrm{~A}$. Science 280: $1258-1261$.

Westphal RS, Tavalin SJ, Lin JW, Alto NM, Fraser ID, Langeberg LK, Sheng M, Scott JD. 1999. Regulation of NMDA receptors by an associated phosphatase-kinase signaling complex. Science 285: 93-96.

Wheeler DG, Barrett CF, Groth RD, Safa P, Tsien RW. 2008. CaMKII locally encodes L-type channel activity to signal to nuclear CREB in excitation-transcription coupling. J Cell Biol 183: 849-863.

Wiegert JS, Bengtson CP, Bading H. 2007. Diffusion and not active transport underlies and limits ERK1/2 synapseto-nucleus signaling in hippocampal neurons. J Biol Chem 282: 29621-29633.

Wojcikiewicz RJ, Luo SG. 1998. Phosphorylation of inositol 1,4,5-trisphosphate receptors by cAMP-dependent protein kinase. Type I, II, and III receptors are differentially susceptible to phosphorylation and are phosphorylated in intact cells. J Biol Chem 273: 5670-5677.

Wood MA, Kaplan MP, Park A, Blanchard EJ, Oliveira AM, Lombardi TL, Abel T. 2005. Transgenic mice expressing a truncated form of CREB-binding protein (CBP) exhibit deficits in hippocampal synaptic plasticity and memory storage. Learn Mem 12: 111-119.

Wood MA, Attner MA, Oliveira AM, Brindle PK, Abel T. 2006. A transcription factor-binding domain of the coactivator $\mathrm{CBP}$ is essential for long-term memory and the expression of specific target genes. Learn Mem 13: 609-617.

Wu GY, Deisseroth K, Tsien RW. 2001. Activity-dependent CREB phosphorylation: Convergence of a fast, sensitive calmodulin kinase pathway and a slow, less sensitive mitogen-activated protein kinase pathway. Proc Natl Acad Sci 98: 2808-2813.

Xia Z, Dudek H, Miranti CK, Greenberg ME. 1996. Calcium influx via the NMDA receptor induces immediate early gene transcription by a MAP kinase/ERK-dependent mechanism. J Neurosci 16: 5425-5436.
Xu L, Massague J. 2004. Nucleocytoplasmic shuttling of signal transducers. Nat Rev Mol Cell Biol 5: 209-219.

Yamamoto K, Hashimoto K, Isomura Y, Shimohama S, Kato N. 2000. An IP3-assisted form of $\mathrm{Ca}^{2+}$-induced $\mathrm{Ca}^{2+}$ release in neocortical neurons. Neuroreport 11: 535-539.

Yeckel MF, Kapur A, Johnston D. 1999. Multiple forms of LTP in hippocampal CA3 neurons use a common postsynaptic mechanism. Nat Neurosci 2: 625-633.

Yuste R, Majewska A, Holthoff K. 2000. From form to function: calcium compartmentalization in dendritic spines. Nat Neurosci 3: 653-659.

Zehorai E, Yao Z, Plotnikov A, Seger R. 2010. The subcellular localization of MEK and ERK - a novel nuclear translocation signal (NTS) paves a way to the nucleus. Mol Cell Endocrinol 314: 213-220.

Zhang F, Wang LP, Brauner M, Liewald JF, Kay K, Watzke N, Wood PG, Bamberg E, Nagel G, Gottschalk A, et al. 2007a. Multimodal fast optical interrogation of neural circuitry. Nature 446: 633-639.

Zhang SJ, Steijaert MN, Lau D, Schutz G, Delucinge-Vivier C, Descombes P, Bading H. 2007b. Decoding NMDA receptor signaling: identification of genomic programs specifying neuronal survival and death. Neuron 53: 549-562.

Zhang SJ, Zou M, Lu L, Lau D, Ditzel DA, Delucinge-Vivier C, Aso Y, Descombes P, Bading H. 2009. Nuclear calcium signaling controls expression of a large gene pool: Identification of a gene program for acquired neuroprotection induced by synaptic activity. PLoS Genet 5: e1000604.

Zhang SJ, Buchthal B, Lau D, Hayer S, Dick O, Schwaninger M, Veltkamp R, Zou M, Weiss U, Bading H. 2011. A signaling cascade of nuclear calcium-CREB-ATF3 activated by synaptic NMDA receptors defines a gene repression module that protects against extrasynaptic NMDA receptor-induced neuronal cell death and ischemic brain damage. J Neurosci 31: 4978-4990.

Zhou Z, Hong EJ, Cohen S, Zhao WN, Ho HY, Schmidt L, Chen WG, Lin Y, Savner E, Griffith EC, et al. 2006. Brain-specific phosphorylation of $\mathrm{MeCP} 2$ regulates activity-dependent Bdnf transcription, dendritic growth, and spine maturation. Neuron 52: 255-269.

Zuhlke RD, Reuter H. 1998. $\mathrm{Ca}^{2+}$-sensitive inactivation of L-type $\mathrm{Ca}^{2+}$ channels depends on multiple cytoplasmic amino acid sequences of the $\alpha 1 \mathrm{C}$ subunit. Proc Natl Acad Sci 95: 3287-3294.

Zuhlke RD, Pitt GS, Deisseroth K, Tsien RW, Reuter H. 1999. Calmodulin supports both inactivation and facilitation of L-type calcium channels. Nature 399: 159-162. 


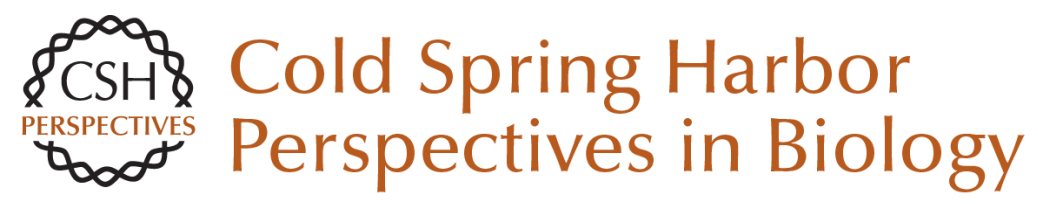

\section{Calcium Signaling in Synapse-to-Nucleus Communication}

Anna M. Hagenston and Hilmar Bading

Cold Spring Harb Perspect Biol 2011; doi: 10.1101/cshperspect.a004564 originally published online July 26, 2011

\section{Subject Collection Calcium Signaling}

The Endoplasmic Reticulum-Plasma Membrane Junction: A Hub for Agonist Regulation of $\mathrm{Ca}^{2+}$ Entry

Hwei Ling Ong and Indu Suresh Ambudkar

Calcium-Handling Defects and Neurodegenerative Disease

Sean Schrank, Nikki Barrington and Grace E. Stutzmann

Lysosomal $\mathrm{Ca}^{2+}$ Homeostasis and Signaling in Health and Disease

Emyr Lloyd-Evans and Helen Waller-Evans

\section{$\mathrm{Ca}^{2+}$ Signaling in Exocrine Cells}

Malini Ahuja, Woo Young Chung, Wei-Yin Lin, et al.

Functional Consequences of Calcium-Dependent Synapse-to-Nucleus Communication: Focus on Transcription-Dependent Metabolic Plasticity Anna M. Hagenston, Hilmar Bading and Carlos Bas-Orth

Identifying New Substrates and Functions for an Old Enzyme: Calcineurin Jagoree Roy and Martha S. Cyert

Fundamentals of Cellular Calcium Signaling: A Primer

Martin D. Bootman and Geert Bultynck
Primary Active $\mathrm{Ca}^{2+}$ Transport Systems in Health and Disease Jialin Chen, Aljona Sitsel, Veronick Benoy, et al.

Signaling through $\mathrm{Ca}^{2+}$ Microdomains from Store-Operated CRAC Channels Pradeep Barak and Anant B. Parekh

Structural Insights into the Regulation of $\mathrm{Ca}^{2+}$ /Calmodulin-Dependent Protein Kinase II (CaMKII) Moitrayee Bhattacharyya, Deepti Karandur and John Kuriyan

Store-Operated Calcium Channels: From Function to Structure and Back Again Richard S. Lewis

Bcl-2-Protein Family as Modulators of $\mathrm{IP}_{3}$

Receptors and Other Organellar $\mathrm{Ca}^{2+}$ Channels Hristina Ivanova, Tim Vervliet, Giovanni Monaco, et al.

Calcium Signaling in Cardiomyocyte Function Guillaume Gilbert, Kateryna Demydenko, Eef Dries, et al.

Cytosolic $\mathrm{Ca}^{2+}$ Buffers Are Inherently $\mathrm{Ca}^{2+}$ Signal Modulators Beat Schwaller

For additional articles in this collection, see http://cshperspectives.cshlp.org/cgi/collection/

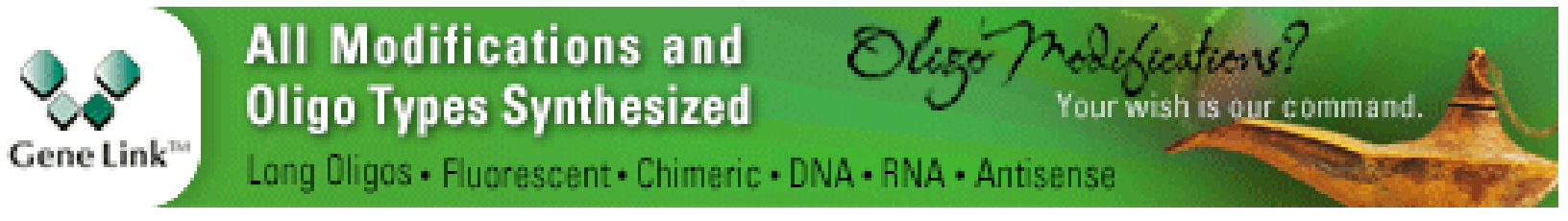


Role of Two-Pore Channels in Embryonic Development and Cellular Differentiation Sarah E. Webb, Jeffrey J. Kelu and Andrew L. Miller

\section{Organellar Calcium Handling in the Cellular \\ Reticular Network}

Wen-An Wang, Luis B. Agellon and Marek Michalak

For additional articles in this collection, see http://cshperspectives.cshlp.org/cgi/collection/

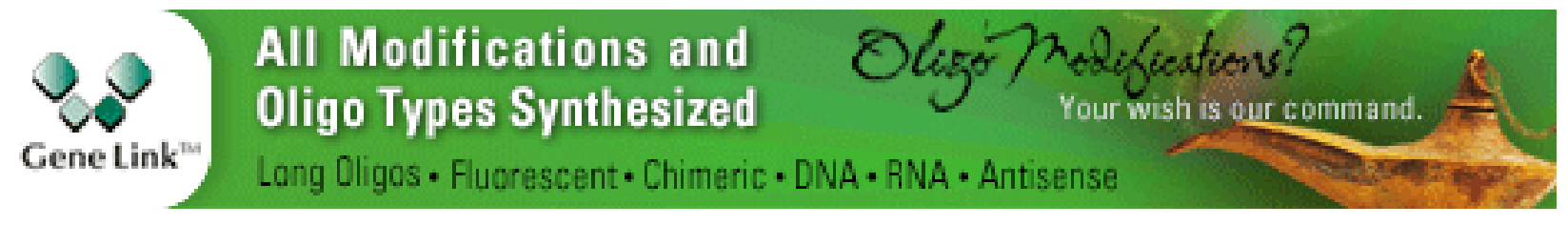

Copyright @ 2011 Cold Spring Harbor Laboratory Press; all rights reserved 